\title{
Justice, Accountability and Social Reconstruction: An Interview Study of Bosnian Judges and Prosecutors
}

\author{
By \\ The Human Rights Center and the International Human \\ Rights Law Clinic, University of California, Berkeley, \\ and the Centre for Human Rights, \\ University of Sarajevo
}

I.

Preface

This study of judges and prosecutors in Bosnia and Herzegovina (hereinafter "BiH") is the first report in a multi-year study undertaken by the University of California, Berkeley, Human Rights Center regarding the relationship between justice, accountability and reconstruction in the former Yugoslavia. ${ }^{\perp}$ The Human Rights Center conducts interdisciplinary research on emerging issues in international human rights and humanitarian law. The International Human Rights Law Clinic at the University of California, Berkeley School of Law (Boalt Hall) and the Centre for Human Rights at the University of Sarajevo collaborated with the Human Rights Center to conduct this study. The International Human Rights Clinic engages law students in projects designed to promote and strengthen human rights protections in national, regional and

1. This study is part of Communities in Crisis, an interdisciplinary, multi-institutional project of the Human Rights Center, University of California, Berkeley that is examining the relationship between the pursuit of international justice and local approaches to social reconstruction in the aftermath of genocide in Rwanda and the former Yugoslavia. Communities in Crisis seeks the following policy outcomes:

- To provide national and international policy makers, including those associated with the ad hoc tribunals and the International Criminal Court, with the first transnational study of the relationship between the pursuit of justice by international tribunals and local efforts at social reconstruction;

- To encourage transnational coalition building among university researchers and activists on issues of justice, development, and reconstruction;

- To broaden conceptions of accountability so as to foster community-based projects that combine advocacy for human rights with economic, social, and development programs; and

- To support the active participation of communities in researching their needs and developing programs. 
international fora. The Centre for Human Rights seeks to build capacity within $\mathrm{BiH}$ to conduct human rights research as well as to integrate the study of human rights into university curricula.

Clinical Professor Harvey Weinstein, Associate Director of the Human Rights Center, Lecturer-in-Residence Laurel Fletcher, Associate Director of the International Human Rights Clinic and Ermin Sarajlija, then Acting Director of the Centre for Human Rights directed this project with the participation of Clinic interns Damir Arnaut, Daska Babcock-Halaholo, Kerstin Carlson, Brian Egan, Anne Mahle, Joyce Wan and Nazgul Yergalieva as well as Bosnian law students Edisa Peštek, Gordan Radić and Tamara Todorović. Professor Zvonko Miljko, University of Mostar (West), Assistant Elmedin Muratbegović, Univesity of Sarajevo and Professor Rajko Kuzmanović, University of Banja Luka served as faculty liaisons to the researchers during the field work portion of the study. The report was written by Professors Fletcher and Weinstein and Clinic interns Arnaut, Babcock-Halaholo, Carlson and Mahle. The researchers gratefully acknowledge the significant contribution of the staff of the Centre for Human Rights in Sarajevo, Acting Director Dino Abazović, Librarian and Archivist Saša Madackić and Progamme Officer Aida Mehiević.

II.

\section{Executive Summary}

This report describes the findings from an interview study conducted in June, July and August of 1999, of a representative sample of thirty-two Bosnian judges and prosecutors with primary or appellate jurisdiction for national war crimes trials. The purpose of this study was to assess the understanding of attitudes among these legal professionals towards the International Criminal Tribunal for the former Yugoslavia (hereinafter "ICTY" or "Tribunal") and prosecution of war crimes. We sought to clarify objections and resistance to the ICTY by examining: (1) the acceptability of international justice; (2) the factors that may contribute to misunderstandings or non-acceptance of international criminal trials; and (3) the perceptions of the relationship between criminal trials and social reconstruction. Based on our analysis of the findings we offer recommendations to strengthen the relationship between the Tribunal and the Bosnian legal community.

Our findings suggest that across national groups, participants supported the concept of accountability for those who committed war atrocities. Yet, the extent of support for the ICTY varied by national group. Participants generally lacked a clear understanding of the procedures of the Tribunal and were poorly informed about its work. However, all desired impartial information about the Tribunal with legal content, since judges and prosecutors had limited or no access to legal publications from or about the ICTY. A universal criticism of the ICTY by legal professionals was that they perceived their sporadic contact with the Tribunal as a sign of disrespect. Moreover, they expressed several areas of concern with the ICTY: its unique blend of civil and common law procedures; the way in which cases are selected; the way in which indictments are issued - 
particularly sealed indictments; the length of detention and trials; and the evidentiary rules applied by the Tribunal. In some of these areas, participants of particular national groups expressed reservations unique to that national group. For example, the Bosnian Serb and Bosnian Croat participants disapproved of or questioned the use of sealed indictments. Further, virtually all participants in these two groups expressed concern that the ICTY was a "political" organization; in this context, "political" meant biased and thus incapable of providing fair trials.

Several themes and topics emerged on which participants across all national groups expressed consistent views, including:

Professionalism: Participants consistently emphasized their strong adherence to high professional standards, and associated professionalism with the strict application of legal rules to a particular case.

Justice: Participants supported the principles of justice and the impartial application of the law, even in instances in which the judicial verdict ran counter to public opinion.

Western European Legal Tradition: Participants viewed the Bosnian legal system as part of the Western European legal tradition and supported reform of the legal code to make it consistent with that of the developed European democracies.

Corruption and Decline in Standards: Participants denounced corruption - which they defined narrowly as bribery - in the legal profession in general and emphasized that they and their immediate colleagues did not engage in corrupt practices. Nevertheless, judges and prosecutors expressed grave concern about the impact on the legal profession of the loosening of professional standards during the war and the decline in the social status of the profession.

Politics: Participants cited financial dependence on the legislature as the primary threat to the independence of the judiciary. Judges and prosecutors denounced the destructive effects of political parties on the judicial system.

International Community: Participants supported efforts of the international community to strengthen the independence of judges and prosecutors. However, legal professionals criticized international organizations operating in $\mathrm{BiH}$, commenting that international representatives frequently were unfamiliar with the Bosnian legal system and acted arbitrarily to impose external rule on the country and its legal institutions.

The impact of national identity clearly became evident as participants discussed their views regarding national groups; the role of the State; responsibility and accountability for the war; genocide; the role of the ICTY and the future of BiH. For example, with regard to genocide, Bosniak participants primarily believed that Serb forces had committed acts of genocide against Bosniaks while Bosnian Serb legal professionals generally stated either that they did not have sufficient information to give an opinion or that genocide was committed by all three 
sides. As well, most Bosnian Croat participants stated that acts of genocide occurred on "all three sides."

The implications of these findings are considered in Discussion $(\S \mathrm{V})$. Based on our findings and analysis we recommend that the appropriate authorities:

- enact legislation that ensures the independence of the judiciary in both entities in $\mathrm{BiH}$;

- institutionalize regular and sustained professional contact between legal professionals in each entity;

- adjudicate war crimes trials in each entity by a panel of three judges, one of whom should be a judge who is not a citizen of $\mathrm{BiH}$ or of any of the states of the former Yugoslavia;

- pursue the option of conducting ICTY trials on the territory of BiH supported by a rigorous protection program for witnesses, judges and legal professionals;

- amplify the ICTY outreach program;

- examine a range of alternatives to criminal trials to promote social reconstruction through the organization of an inter-entity council sponsored by the Office of the High Representative ("OHR"); and

- incorporate appropriate International Criminal Court (hereinafter "ICC") mechanisms to ensure transparency and accessibility with attention paid to the needs and concerns of the directly affected communities and their legal practitioners.

III.

\section{INTRODUCTION}

"The court was formed in Nuremberg where the war criminals were tried, and after that and despite that, the war criminals appeared throughout the world. And it will be so in the future. They cannot be deterred."

Bosnian Judge

“The Hague Tribunal doesn't serve justice. Look at that war criminal, Erdemović, who received five years for killing over seventy people. It is unjust that he should receive such a light sentence."

Woman of Srebrenica

"You cannot correct The Hague when it was planted and rooted badly. It was wrong in how it was established, structured, and funded. We want to relieve [former ICTY Prosecutor Louise] Arbour and have them tried here - but in what courts? They would be obstructed by the entire structure."

Bosnian Journalist

"People do not have confidence in the Tribunal. But it is the only light at the end of the tunnel. Without it, there would be no justice and this would be the final betrayal." 
The purpose of this study was to examine issues raised in four distinct areas:

(1) Is international justice acceptable to judges and prosecutors who work within a national framework?

(2) What factors contribute to misunderstandings or non-acceptance of international criminal trials?

(3) How do judges and prosecutors in Bosnia and Herzegovina perceive the relationship between criminal trials and social reconstruction?

(4) What processes can be put into place to facilitate the acceptance by the national legal system of an international court?

\section{A. The Problem}

This report is part of a larger study examining traditional assumptions regarding justice, accountability, and reconstruction in the aftermath of mass violence and genocide. Although the international community has paid much attention to conflict resolution and diplomatic mechanisms of violence prevention, it has devoted less attention to identifying the necessary aspects of the process of rebuilding a country torn apart by sectarian strife. ${ }^{2}$ After initial humanitarian intervention has provided the necessities for survival, long-term development traditionally has focused primarily on economic factors while ignoring the social and psychological issues that precipitated the violence or arose as its consequence. How postwar societies understand the past, assign responsibility for atrocities committed and struggle to reconstruct divided communities is a multifaceted process about which there are many opinions but little understanding. Further, although conventional wisdom holds that criminal trials promote several goals, including uncovering the truth; avoiding collective accountability by individualizing guilt; breaking cycles of impunity; deterring future war crimes; providing closure for the victims and fostering democratic institutions, little is known about the role that judicial interventions have in rebuilding societies. ${ }^{3}$

In May 1993, the United Nations Security Council created an ad hoc international tribunal to try alleged perpetrators of war crimes committed since 1991 in territory the former Yugoslavia. ${ }^{4}$ As noted in an ICTY document, one of its goals is to serve "as a means to assist in reconciliation and to prevent a recurrence of conflict." However, unlike the Nuremberg and Tokyo tribunals, the ICTY is not the product of "victor's justice." The Tribunal, established under the auspices of the international community, has been charged with the prosecution of war crimes committed by all parties to the conflict. Nevertheless, as we

2. Carnegie Commission on Preventing Deadly Conflict, Preventing Deadly ConFLICT (Dec. 1997).

3. Mark Osiel, Mass Atrocity, Collective Memory, and the Law 6-10 (1997).

4. S.C. Res. 808, U.N. SCOR, $48^{\text {th }}$ Sess., $3175^{\text {th }} \mathrm{mtg}$., U.N. Doc. S/RES/808 (1993); S.C. Res. 827, U.N. SCOR, $48^{\text {th }}$ Sess., $3217^{\text {th }}$ mtg., U.N. Doc. S/RES/827 (1993).

5. International Criminal Tribunal for the former Yugoslavia, Office of the President, Outreach Program Proposal (1999) (unpublished report, on file with the Berkeley Journal of International Law)[hereinafter Outreach Program Proposal]. 
will indicate, many Bosnian Croat and Bosnian Serb legal professionals - members of national groups whose armed forces the international community has condemned as carrying out massive war atrocities - have dismissed the ICTY as a "political" court. Thus, the ICTY is plagued by a crisis of legitimacy in Bosnia.

Citizens of $\mathrm{BiH}$ from all national groups express ambivalence towards the ICTY. Many see the Tribunal as a critical step towards justice, while others see it as a manifestation of outside interference. ${ }^{6}$ Coupled with this concern, many Bosnians and international organizations question the ability of the national judiciary, both in the Federation of Bosnia and Herzegovina (hereinafter "Federation") and in the Republika Srpska (hereinafter "RS"), competently to prosecute war criminals in a non-partisan manner. Finally, since the recently-established ad hoc Tribunals (the ICTY and the International Criminal Tribunal for Rwanda) are holding the first international trials since the Second World War, yet take place in a radically different context, their effect on domestic war crimes trials and their relationship to the domestic judiciary has still yet to be fully understood.

The ICTY procedures and rules of evidence were patterned primarily after the common law system, one unlike the civil law tradition of BiH. The international tribunals at Nuremberg and Tokyo created procedural rules that borrowed from the civil and common law systems. In contrast, the ICTY adopted a "largely adversarial" approach to its proceedings. ${ }^{7}$ As the first president of the Tribunal explained, the judges wanted to remain "as neutral as possible" and therefore rejected most aspects of the civil law system, a system that allocates to the judge the primary task of investigating allegations and gathering the necessary evidence. ${ }^{8}$ We postulated that the choice of procedural rules might have important implications for how accessible the Tribunal appeared to Bosnian judges and prosecutors. Yet there has been little systematic study on the impact that the choice of the rules of evidence and procedure has had on the perceptions of the international body by Bosnian legal professionals.

Despite the challenges posed by international criminal tribunals, United Nations support for international criminal prosecutions is growing, as demonstrated by the recent creation of the statute for a permanent International Criminal Court. ${ }^{9}$ The involvement of the international community in the recent wars in the Balkans marks an important shift toward international intervention in con-

6. The Human Rights Center at University of California, Berkeley, conducted an informal survey of nongovernmental organizations (hereinafter "NGO's"), journalists, academics, survivors and representatives of international organizations in $\mathrm{BiH}$ in the summer of 1998 that defined the scope and nature of this project.

7. Antonio Cassese, President of the International Criminal Tribunal for the Former Yugoslavia, Summary of Rules of Procedure of the International Criminal Tribunal for the Former Yugoslavia, Address at a Briefing to Members of Diplomatic Missions (Feb. 11, 1994) in VIRGINIA Morris \& Michael P. Scharf, An Insider's Guide to the In'ternational Criminal Tribunal for the FORMER YugOSLAVIA 650-51 (1995).

8. Id.

9. Rome Statute of the International Criminal Court, U.N. Duc. A/CONF.183/9 (1998); also available at $<w w w . u n . o r g / l a w / i c c / i n d e x . h t m>$. 
flicts based on humanitarian reasons. Indeed, subsequent interventions in Kosovo and East Timor are recent examples of further erosion of the traditional impunity offered by state sovereignty. The question remains on what basis and where the world community will intervene, but it is apparent that state sovereignty no longer provides the shield against outside intervention that it once did.

International intervention in armed conflict has been linked increasingly to international prosecution for humanitarian law violations committed during such episodes. In addition, the opinion of world leaders and diplomats has coalesced around the idea that international criminal prosecutions are integral to the process of reconciliation in a country that has been torn apart by violence. ${ }^{10} \mathrm{Com}$ ments by Tribunal officials and legal scholars indicate that they too have embraced this larger aspiration - an attribution of the influence of the court that moves beyond the narrowly focused legal mandate of adjudicating criminal trials. ${ }^{11}$ Seven years after the inception of the ICTY, much and little has changed. Despite the continuing resistance of some countries and politicians to cooperate with the Tribunal, the number of arrests has increased and with additional resources, the Tribunal is now firmly established. This is an opportune time to reexamine the policies and practices instituted when the Tribunal was established in the midst of war.

\section{B. The Bosnian Judicial System and the ICTY}

The ICTY has primary jurisdiction for war crimes prosecutions. Nevertheless, a well-functioning national judicial system in Bosnia is critical to any widespread and systematic effort to prosecute accused war criminals. The sheer

10. Upon the conviction of Jean-Paul Akayesu, the Office of the Press Secretary at the White House stated: "Reconciliation, security, and regional development will take hold ... only when the cycle of violence has been broken and accountability established." Office of the Press Secretary, The White House (Sept. 3, 1998) (visited May 9, 2000) <http//:www.pub.whitehouse.gov/>; "Reconciliation cannot begin when justice is delayed for the guilty. As long as justice remains fleeting, the perception of guilt will remain and the difficult process of national reconciliation will end before it has a chance to begin." U.S. Ambassador to the United Nations, Bill Richardson, No Peace Without Justice, report from the Diplomatic Conference of Plenipotentiaries for the Establishment of an International Criminal Court, Rome, Italy (July 15-17, 1999); M. Cherif Bassiouni, Searching for Peace and Achieving Justice, 59 AUT Law \& Contemp. Probs. 9, 23 (1996). See also M. Cherif Bassiouni, The Commission of Experts Established pursuant to Security Council Resolution 780: Investigating Violations of International Humanitarian Law in the Former Yugoslavia, 5 CRIM. L. F. 279,339 (1994); Peter Burns, An International Criminal Tribunal: The Difficult Union of Principle and Politics. 5 CRIM. L. F. 341, 344, 374 (1994).

11. Gabrielle Kirk McDonald, former President of the ICTY stated: "[T]hrough this process, it is our hope that we will deter the future commission of crimes and lay the groundwork for reconciliation. I do not expect the Tribunal to . . somehow magically create reconciliation, but at least we can lay the groundwork." Interview by Eric Stover and Christopher Joyce, with Judge McDonald in The Hague, The Netherlands (July 26, 1999); "This judicial process is essential for reconciliation to begin." Richard Goldstone, Ethnic Reconciliation Needs the Help of a Truth Commission, INT'L HeRALD Trib., October 24, 1998. In addition, the UN Legal Counsel and Under-Secretary General for Legal Affairs Carl-August Fleichhauer stated: "These three important goals [ending war crimes, holding perpetrators accountable and breaking the cycle of ethnic violence and retribution] are intertwined in the fundamental reason for the establishment of this Tribunal ...." quoted in Peter Burns, An International Criminal Tribunal: The Difficult Union of Principle and Politics, 5 CRIM. L.F. 341, 374 n.137 (1994). See Theodore Meron, Answering for War Crimes, Lessons from the Balkans (ICTY), ForeIGN AFF., Jan./Feb. 1997 at 2-8. 
numbers of potential defendants and the resources needed to conduct such trials would overwhelm the capacity of the ICTY. Consequently, accountability for large numbers of war crimes violations will require the active participation of the national courts in $\mathrm{BiH}^{12}$ Yet many Bosnians and representatives of international organizations ask whether the national judicial system is able to meet this challenge.

Complicating this task is the 1996 agreement between the three signatories of the Dayton Peace Agreement (Bosnia-Herzegovina, Croatia, and the Federal Republic of Yugoslavia) titled the "Rome Agreement" or the "Rules of the Road."13 According to this document, Bosnian authorities must submit case files of accused war criminals to the ICTY Office of the Prosecutor (hereinafter "OTP") for review and approval before proceeding with the arrest and trial of such persons. Initially, due to lack of funding, the OTP did not have the resources to conduct an expeditious review of files. As a result, Bosnian judges and prosecutors initiating war crimes trials confronted exasperating delays. At the time of this study, the review process remained a sensitive issue. The initiation of national war crimes trials is an area in which the $\mathrm{BiH}$ legal system and the ICTY intersect. Given the tension surrounding this procedure, we hope to shed light on the manner in which Bosnian judges and prosecutors perceive this institutional arrangement.

Concerns about the Bosnian judicial system have come from such diverse sources as the United Nations Mission in Bosnia and Herzegovina (hereinafter "UNMIB"), ${ }^{14}$ the International Crisis Group (hereinafter "ICG"), ${ }^{15} \mathrm{OHR},{ }^{16}$ the Judicial System Assessment Programme of the United Nations (hereinafter "JSAP") ${ }^{17}$ and the European Stability Initiative (hereinafter "ESI"). ${ }^{18}$ Criti-

12. Neil J. Kritz, Coming to Terms with Atrocities: A Review of Accountability Mechanisms for Mass Violations of Human Rights, 59-AUT Law \& ConteMP. Probs. 127, 133-34 (1996).

13. The Rome Agreements were signed on Feb. 18, 1996 in Rome, Italy. They can be found at <http://www.nato.int/ifor/rome/rome2.htm>.

14. In July 1999, Elizabeth Rehn was reported as saying that Bosnia was becoming: "An El Dorado of organized crime." She indicated her belief that judges were corrupt, prosecutors afraid and witnesses intimidated. RFE/RL NewsLINE July 26, 1999. <http://www.rferl.org/newsline/1999/ 07/260799.html>.

15. International Crisis Group, Rule Over law: Obstacles to the Development of AN INDEPENDENT JUdICIARY IN BIH, ICG Report No. 72 (1999) [hereinafter ICG REPORT RULE OVER Law]; International Crisis Group, Rule of Law in Public Administration: Confusion and Discrimination in a Post-Communist Bureaucracy, ICG Balkans Report No. 84 (1999).

16. Report of the High Representative for Implementation of the Bosnian Peace Agreement to the Secretary-General of the United Nations, Office of the High Representative, para. 65 (March 14, 1996); para. 113 (April 14, 1997); para. 92 (July 11, 1997); para. 69 (Jan. 16, 1998); para. 81, 82 (April 9, 1998); para. 99, 100 (July 14, 1998); para. 83 (Oct. 14, 1998); para. 68 (Feb. 12, 1999); para. 64, 68, 100 (May 7, 1999); para. 43, 48, 49 (July 16, 1999); para. 56, 57, 59, 61, 65 (Nov. 11, 1999).

17. United Nations Mission in Bosnia and Herzegovina [hereinafter UNMIB], Judicial System Assessment Programme [hereinafter JSAP], Report for the Period November 1998 to JANuARY 1999 (1999); UNMIB, JSAP, Thematic Report III: ON ARrest WarRants, AMNESTY AND TRIALs In Absentia (December 1999); UNMIB, JSAP, COMMENTS ON THE INDEPENDENCE OF THE JUDICIARY (February 2000).

18. European Stability Initiative, Reshaping International Priortties in Bosnia and Hercegovina: Part One, Bosnian Power Structures (1999). 
cisms have focused on lack of judicial accountability; corruption of judges and judicial ministries; intimidation by nationalist political parties and criminal elements; lack of enforcement of judicial decisions by police; political resistance to a unified judicial system in the Federation; poor inter-entity cooperation; financial dependence of judges on the political system; politically-influenced judicial appointments; inexperienced judges; lack of resources for efficient management and poor distribution of relevant legal material. These problems reflect the transition from the Communist system based on patronage and control as well as the profound effects of the war that damaged infrastructure and economic stability. These observations suggest that there are vulnerabilities within the Bosnian legal system that influence its relationship to the Tribunal.

Attempts to address these identified problems have been undertaken by several international organizations such as JSAP, OHR, the Council of Europe, the Central and Eastern European Law Initiative of the American Bar Association (hereinafter "ABA/CEELI"), and the International Human Rights Law Group. These initiatives have focused on education of judges on the European Convention on Human Rights and international human rights and humanitarian laws as well as monitoring of trials to assess whether they meet international standards. The success of these efforts has not been evaluated. More importantly, there has been no formalized attempt to ascertain the views of Bosnian legal professionals regarding the professional capacity and/or problems of the Bosnian judicial system, or their impressions of the educational interventions undertaken by the international community. This study represents the first attempt to gather systematic data on these important issues.

\section{The ICTY Outreach Program}

Effective collaboration between a national judiciary and an international tribunal depends in part on the integrity of each judicial institution and on the mechanisms of communication established between the two structures. Beginning in 1997, Judge Gabrielle Kirk McDonald, then President of the ICTY, became increasingly concerned about the gap that existed between the Tribunal and those most affected by its decisions: the peoples of the former Yugoslavia. With the realization that the Tribunal was viewed negatively by many in the Balkans, President McDonald invited a group of legal professionals to The Hague in October 1998, to observe the Tribunal and its workings first-hand. ${ }^{19}$

Further, in November 1998, President McDonald sent a group of ICTY staff to Bosnia to assess the problem of a lack of understanding of the Tribunal among the people. The mission members reported a "strong desire" for information and direct involvement with representatives from the Tribunal and they proposed the creation of an Outreach Program located within the Office of the Registrar and urged that the capacity of the Public Information Unit be enhanced. With a focus on disseminating accurate information and increasing dialogue, the program is "intended to engage existing local legal communities and

19. Outreach Program Proposal, supra note 5. 
non-governmental organizations, victims' associations, and educational institutions."20 In 1999, the Outreach Program opened offices in Zagreb, Croatia and Banja Luka, BiH.

The Outreach Program has the potential to ameliorate the schism in understanding between the ICTY and the people of the former Yugoslavia. In light of the critical role that the national legal system plays in the internationalized framework for criminal justice, it will be necessary to win the support of Bosnian judges and prosecutors. This project was undertaken, in part, to strengthen this objective.

\section{Methodology}

The project employed qualitative methods to allow the judges and prosecutors to discuss their views in response to a series of open and closed-ended questions. Qualitative research uses methods including observation, study and analysis that can illuminate experience in ways that surveys or more quantitative approaches do not. Data is gathered through interviews, focus groups, field observations, participant observation and analysis of published sources of information. The advantage of the approach is the richness of the information obtained; the principal disadvantage is that the sample is non-random and that careful attention must be paid to such issues as validity and bias.

(1) Study Design: The field research consisted of in-depth, semi-structured interviews of thirty-two judges and prosecutors during June, July and August of 1999 , in $\mathrm{BiH}$. The length of the interviews ranged from two to six hours. Trained teams of researchers conducted the interviews. There were three teams, each consisting of two researchers (one from the United States, one from BiH) and a faculty liaison. One team, based in Sarajevo, primarily interviewed participants in the Bosniak-majority areas of the Federation (the "Sarajevo Group"). The Bosnian researcher and faculty liaison were Bosniaks. Another team, based in Banja Luka, interviewed participants exclusively in the Republika Srpska and in Brčko (the "Banja Luka Group"). The Bosnian researcher and faculty liaison were Bosnian Serbs. The final team, based in Mostar, primarily interviewed participants in the Bosnian Croat-majority areas of the Federation (the "Mostar Group"). The Bosnian researcher and faculty liaison were Bosnian Croats. Faculty liaisons were recruited from the universities of Sarajevo, Banja Luka and Mostar (West).

(2) Sample: Criteria were developed to ensure a representative sample of judges and prosecutors. These criteria included:

(a) Jurisdiction: For the Sarajevo Group, of the twelve interviews, seven were with judges in cantonal courts, courts of first instance for war crimes trials; two with judges from the Federation Supreme Court, which has appellate jurisdiction for such cases and one with a judge from the Federation Constitutional Court. The final two interviews were with prosecutors with jurisdiction to seek indictments for war 
crimes. For the Banja Luka Group, of the ten interviews, three were with judges in the basic courts, courts without jurisdiction for war crimes cases; three were with judges in district courts, courts which have jurisdiction for war crimes cases; and two were with judges from the RS Supreme Court. The final two interviews were with prosecutors; one had jurisdiction to seek indictments for war crimes and one did not. For the Mostar Group, of the ten interviews, four were with judges in the basic court, courts of first instance for war crimes trials in the region; four were with judges in the cantonal courts, courts with appellate jurisdiction of war crimes trials in the region; and the final two were with prosecutors, one of whom had jurisdiction to seek war crimes indictments and the other was a cantonal prosecutor who represented the state in appellate review of such trials.

(b) Geographic Distribution: Judges and prosecutors were selected from the various regions of $\mathrm{BiH}$.

(c) Demography: Age, level of experience and gender were considered in selection of judges. Membership in a particular national group was not a selection criterion. Nevertheless participants belonged overwhelmingly to the national group that constituted a majority in that particular area.

(3) Questionnaire: The researchers created a semi-structured questionnaire of forty-five items. ${ }^{21}$ The items were translated into the appropriate languages and then back translated to ensure accuracy. The questionnaire was reviewed by all team members and was pre-tested. Topic areas included:

(a) Demographics: education and legal experience; personal background; national background and the impact of the war;

(b) Role of the judge/prosecutor and courtroom process in $\mathrm{BiH}$;

(c) Domestic effects of the ICTY: legal definitions of accountability and the rule of law; social reconstruction and war crimes; genocide; the role of the Dayton Accords and international law; and perceptions of the ICTY, including its goals, choice of those indicted, knowledge of specific trials and Rules of the Road, sources of information about the ICTY, and its effects on the participant's legal practice as well as on the country as a whole;

(d) Domestic war crimes trials, including procedures, personal experience with war crimes trials and the effects of such trials; and

(e) Hopes for the future.

We were concerned that the sensitive nature of some of the questions would hinder open and honest responses. Therefore interviewees were assured of confidentiality in their answers and all members of the research team, including translators, signed pledges of confidentiality. Interviews were carried out in the privacy of the participants' offices except where the judge or prosecutor preferred another setting. Furthermore, we have not identified the sources of

21. See Appendix A. 
any quotations used in this report to protect the confidentiality of the participants.

(4) Study Limitations: As a qualitative study, the data may be limited by the small size and non-random nature of the sample. The trade-off is the depth of the information reflected in almost 150 hours of transcribed interview material. By establishing clear criteria, every effort was made to assure that the sample was representative. Since the faculty liaisons contacted the interviewees, it is possible that selection bias was present. Other possible threats to validity include the small number of women interviewed, the need to work through interpreters, as well as the possible need of the legal professionals to present themselves in a favorable light to Western researchers. Cultural and national biases of interviewers, interpreters and the researchers must always be kept in mind when these data are analyzed. Since most of the legal professionals were male and five of the six interviewers were female, gender bias may have influenced the interviewee responses. The accuracy of the translation of the participants' comments was improved by the presence of a Bosnian researcher and an interpreter in every interview. Further, all taped interviews were reviewed by a native speaker to assure accuracy of translation.

(5) Analysis: Each interview was taped, transcribed and checked for accuracy. Field observations were noted and recorded. Within each team, every interview was reviewed separately by each team member and coded according to key concepts developed by the research group. In addition, the University of California project directors and a member of each team reviewed the interview transcripts of all three teams. Team members reviewed their coding together and finally, cross-team comparisons were conducted.

\section{IV. \\ FINDINGs $^{22}$}

Our sample consisted of twenty-six judges and six prosecutors. ${ }^{23}$ They were predominately of middle age and had occupied their positions for several years prior to the onset of the war. For the judges, the median number of years on the bench was 13.5. The prosecutors had occupied their positions for a median of seventeen years. Nine of the participants were Bosnian Serb, twelve were Bosnian Croat and eleven were Bosniak. The principal limitation of the study was the small number - only six - of female participants. Among the judges, forty-two percent lost their housing and seventy-three percent reported that a relative had been injured or killed during the war. Thirty-three percent of the prosecutors had lost their homes and a similar percentage indicated injury or death of relatives.

22. We have attempted to describe accurately the significant themes that emerged among participants. Where it is helpful to illustrate important differences of perception, we have provided precise numerical data regarding the responses.

23. See Appendix B, Tables 1 and 2 . 


\section{A. Common Themes Among Participants in the RS and in the Federation}

\section{Participants Identify as Professionals}

All participants highlighted the importance of professionalism. This theme, commonly found among participants in both entities, is an important finding because it was one of the few areas on which all agreed. Participants equated professionalism generally with pride in work, strict adherence to legal rules, impartiality, objectivity and the independence of the judiciary. Participants also used the term "professionalism" to refer to a duty to support, uphold and enforce the rule of law as well as the social norms of fairness and equity. Further, the interview data suggest that these aspirations for their professional role were intimately bound up with participants' social status and self-definition.

The judges and prosecutors described their work as involving the strict and objective application of legal rules to a particular case. Participants explained that the primary role of the judge and prosecutor in the civil law system was to determine which provision of the legal code applied to the case at hand. Judges and prosecutors frequently referred to the legal code as the basis of legal authority which they were duty-bound to apply. Thus, they viewed the essence of their professional competence as the ability solely to select and apply the appropriate law.

One example that demonstrates how judges and prosecutors understood the limits of their professional roles lies in the area of refugee returns. Participants made a clear distinction between the prerogatives of politicians to define the conditions under which refugees could return and their own roles in applying property rights for returning refugees as defined in the legal code. No participant indicated that a judge was empowered to interpret the law beyond that which was written in the code. For example, when asked what role a judge might play in facilitating refugee returns, one participant responded: "The court is an independent body and has no active role in the return of refugees. But it does have a role in the case of disputes of which I mean, personally, I can only speed up the process of bringing a person's case to court, that is all I can do." 24

Participants defined professional status to include their external presentation and professional conduct. The role of a legal professional in the community was defined by how and where one is seen in public, adherence to high standards of morality and conduct and professional dignity. For example, several participants remarked that judges must choose "with care" the restaurants they frequented since their appearance in public reflected their degree of professionalism.

Participants also were concerned about the moral and ethical standards that enhanced the dignity of the profession. Participants described the importance of professional integrity and each averred that they met their own high standards of judicial professionalism. Participants identified lack of impartiality, corruption, lower expectations for newcomers to the legal profession, and political pressures

24. The quotes provided may have been modified through correction of grammar in order to make the meaning clear. 
leading to a lack of independence on the part of legal professionals as unacceptable characteristics and problem areas in the Bosnian judiciary.

\section{Belief in the Principles of Justice}

All participants valued the ideal of justice. Many reported that the Bosnian legal system supported this principle. As proof, participants pointed to the legal code as the embodiment of this normative value. Participants generally equated justice with the equal application of law. In accordance with the principles of professionalism, they stated that the personal beliefs, attitudes or morals of the individual judge or prosecutor were irrelevant to the administration of justice. As one participant stated: "The judge acts only according to law. Only." Participants further described that the purpose of the judicial system was to promote specific and general deterrence of criminal conduct, inculcate normative values and rectify inequities. As one judge noted: "A judicial decision can effect or change people's behavior. The court has a role to prevent future behaviors."

Participants saw their capacity to be objective as paramount to the administration of justice. They saw their own opinions as objective, honest and correct. For example, when asked about genocide, one judge stated: "When you look objectively, that's [genocide] that happened." In addition, another participant noted: " $[\mathrm{A}]$ judge shouldn't have any complex that he is infallible. He should stand with his feet on the ground. He shouldn't have any prejudice if he is a real judge. . . . A judge should be an honest man." Other participants agreed that "good" and "correct" decisions promoted justice.

While noting the value of objectivity, participants agreed that justice was also a function of perception. Participants were aware that those affected by their decisions did not always see the outcomes as just. Or, as another participant put it: "I think our courts conduct fair trials here. However, there are many of our verdicts with which everyone is dissatisfied." Despite the fact that parties to a dispute as well as the public might disagree with a judicial outcome, participants were convinced that if they applied the law strictly to the facts, the public would perceive the judicial system as trustworthy and fair. As one participant stated: "If a judicial decision is made according to the law, this can impart a feeling of righteousness to the parties, no matter if the decision is positive or negative for them." Nevertheless, another participant noted that publicity surrounding court decisions increased public pressure on judges.

Finally, participants acknowledged that in certain cases, impartial application of the appropriate legal rule did not produce justice. Nevertheless, legal professionals reported they were constrained by their professional obligations to apply the law in these instances. As one prosecutor stated: "You always have to stick to the legal solution. The fact is that although something is legal does not mean that it is just." Another judge echoed this sentiment: "Sometimes people think that we are doing our job wrong, but we only do our work as it is prescribed by the law." 


\section{Participants Identify with the Western European Legal Tradition}

Participants from all three national groups highlighted the significance that Western European culture and legal traditions have had on their work. Participants were aware that the social and economic conditions resulting from the war have increased the disparity between Bosnia and Western Europe. However, participants expressed a strong desire to integrate with Western Europe, to move toward a more Western European ideal. Participants made frequent comparisons between Bosnia and countries in Western Europe, suggesting it was not simply legal integration they desired but also the Western European standard of living. For some, such integration required changes internal to Bosnia. As one participant stated: "We can't go to Europe in peasant shoes." Clearly, it was important to these legal professionals that Bosnian laws are either integrated with, or comparable to, the laws of Western Europe.

Several participants spoke of the importance of human rights protections. Additionally, some spoke of the integration of European and international treaties into Bosnian law through the Dayton Agreement and one judge discussed the need for his colleagues to study the European Convention on Human Rights (hereinafter "European Convention") and its application to domestic criminal procedures. Another saw the incorporation of expanded due process rights in the Federation's new Criminal Code as evidence that Bosnia's legal system was rising to the standards of Western Europe: "It's a degree of a developed civilization that protects the rights of indicted or accused persons; democratic rights are the very rights of accused persons."

Participants also cited the abolition of the death penalty - brought about as a result of the application of the European Convention to BiH through the Dayton Agreement - as an example of legal reform. However, participants differed in their assessment of this development. Some who favored abolition of the death penalty welcomed the change. However, others characterized the new rule as an intrusion by the international community into domestic affairs, whether or not they supported the death penalty.

\section{Decline in Status and Professional Standards}

The once privileged status of Bosnian legal professionals is in decline. Participants acknowledged informal rules and customs in pre-war Yugoslavia that conferred influence, social status, privileges and obligations which the judges and prosecutors readily accepted. In fact, many participants reported that they had chosen the legal profession because of the social status associated with it. However, some criticized the special treatment that judges who were active members of the Communist Party received in pre-war Yugoslavia: "There was a lot of 'party' in the Party meetings! They didn't do work." Nevertheless, participants believed it remained the responsibility of the State to provide adequate material support for judges and prosecutors. "The state, the government, must provide elementary conditions. First of all, an adequate salary, an apartment, so 
the judge doesn't have to think about those problems. So his basic problem can be how, in the most successful way, to perform his function."

In addition to unpaid salaries, benefits once provided by the State such as apartments for judges and prosecutors are fast disappearing and frequently those provided were seen as substandard. Thirteen participants - almost half - were displaced by the war. Several others expressed two concerns. First, they were frustrated and angry that they had been unable to reclaim their former apartments. One participant, who was living in a rented apartment, explained that he was forced to do so because he could not regain possession of his former apartment which was also located within the city in which he worked: "I have a three bedroom flat ... which is a hundred meters away from here. And in my apartment are people who are not refugees or displaced persons." Second, participants who had been given state-owned apartments were dissatisfied with the quality of their current housing. One participant reported that he lived separately from his family because his government-provided one-room apartment was too small - thirty-eight square meters (approximately 350 square feet).

Legal professionals reported dissatisfaction with the impact of the post-war economy on their social status. For example, one participant stated: "You have people [like legal professionals] who have studied all their life . . . but their salaries are incredibly small, unlike the salaries of the people who have no schooling whatsoever, they're earning millions of marks. These are the absurdities." One participant reported that a one-night stay in a hotel in Vienna cost the equivalent of one month's salary, highlighting the discrepancy between the standard of living for legal professionals in Bosnia and those in Western Europe. In particular, two participants explicitly reported that the diminution of status, salary and benefits has led them to consider other job opportunities. One veteran legal professional stated: "This is only a transitional period for me. Most probably, I will start working as a lawyer." The other explained that being a judge in Bosnia is "not the same job that it is in the West, as it should be" and stated he might become an attorney "because it's a better-paid job, nothing more."

The war has brought significant changes to the profession, such as the impact of the decline in professional standards during the war. The qualifying test for judicial candidates reportedly was easier in the midst of the conflict. One participant reported that judges elected during the war did not have to pass the judges' examination at all. ${ }^{25}$ Many participants reported that this loosening of requirements had denigrated the profession.

Participants stressed the importance of well-educated and well-informed legal professionals, and they equated legal experience with competence. As one judge stated: "I think it would be a good thing if more judges were more educated, had more life and work experience. This might require that they work as lawyers before becoming a judge." Many participants suggested that declining salaries and benefits attracted fewer promising candidates. In addition, partici-

25. This participant indicated that during the war the authorities sought to address the shortage of judges by passing a special law that allowed individuals to become judges with only a law degree. He stated that this practice was discontinued after the war. 
pants emphasized the importance of judges serving as mentors to develop the skills of newcomers to the judiciary and noted that the loss of experienced judges since the war has decreased the number of senior judges available to perform this role. Participants also cited the migration and subsequent loss of so many experienced legal professionals due to the war as a contributing factor both to the diminished competence and lessened status of the profession. As one legal professional remarked: "There are some judges in lower courts who are just there by accident." Many participants believed that unqualified judges should be removed to maintain high standards of judicial professionalism.

\section{Corruption}

Participants questioned the accusations of corruption that had been leveled against the Bosnian judicial system by the international community. Participants appeared to define corruption narrowly - as taking money in exchange for a particular outcome, i.e., bribery. Using this definition, participants frequently stated that they and their immediate colleagues did not engage in corrupt practices. For example, in discussing the issue of corruption one lower court president stated simply: "not in my court."

Other participants, however, alluded to corruption around them: "I am a professional, but I cannot speak to the professionalism of my colleagues." In response to the question: "Is a fair trial possible in Bosnia?" one participant thoughtfully stated: "I don't know. There's a different person sitting behind every desk. As far as [my city] and my authority go, everything is in order. The first time it is out of order, I won't work."

Participants speculated on the impact of low or unpaid salaries for judges and prosecutors. Many participants discussed the fact that judges and prosecutors were prohibited from accepting employment outside their profession, even to augment their low state salaries. Participants related the need for adequate salaries to an independent judiciary and suggested that some colleagues engaged in outside employment, possibly compromising professional duties. One described behavioral changes that indicated to him that the professional integrity of his colleagues possibly had been compromised by accepting outside work: "They are less interested in their daily job duties; they are often absent." Another stated: "You need to ... make a judge independent in every way. Because if you have to beg in other ways - to make money privately from a friend - it's different, there are consequences."

Several Bosniak participants noted that the objectivity of legal professionals also was compromised by threats to their personal security and that of their families. As one participant explained: "It's not easy for judges to make a judgment if before the trial they get a threat that their family will be killed." Another observed that such threats, when issued with impunity, had a chilling effect on both the targeted judges and their colleagues. 


\section{Politics}

All participants used the term "politics" or "political" primarily to distinguish between a legal process - a process governed by a fixed set of rules that can be applied in a neutral manner - and a process by which decision-makers exercise discretion to achieve a particular policy goal or desired outcome. Frequently, judges and prosecutors adamantly reiterated the distinction between themselves, as legal professionals, and politicians. In addition, participants repeatedly expressed their personal distaste for politics and politicians and vigorously criticized the overt and indirect influence of political parties on the legal system.

Participants equated politics with bias. Participants felt that politicians operated for corrupt, personal reasons, against the interests of the populace and without transparency. As one judge stated:

I do not trust the politicians that much. A person who is applying the law should believe in the other parts of government. But considering how many of them just came to the top and made so much money, I am afraid that there are not that many who honestly believe in the rule of law. Because if they had that honest belief, then we would not have so many problems.

Politics and political decisions were declared by some participants to be defined by nationality. One participant stated that all political parties were connected to a national group, and that the lack of a political party not tied to a nationality "forces" people into political parties according to nationality. Virtually all participants agreed that politicians played a destructive role in the war and agreed that politicians brought a war no one wanted. As one participant stated: "Who ordered this war? Who is accountable for it? It was politicians." Furthermore, participants saw the on-going political problems of the State as a reflection of the parochialism of the political parties.

Judges and prosecutors frequently declined to respond to questions regarding their personal views of the judicial system and its application of laws, stating that those were "political questions." Participants also responded to questions regarding controversial issues such as genocide or the creation of a State Supreme Court of Bosnia and Herzegovina by noting that these too were "political" questions. ${ }^{26}$

In pre-war Yugoslavia, virtually all judges were members of the Communist Party, including most of the legal professionals in this study. However, participants reported varied levels of more recent involvement in political parties and structures. For example, many participants served as military judges and prosecutors during the war. Others were directly involved in political structures. One participant actively supported the military efforts of the Croatian Defense Council (hereinafter Hrvatsko Vijeće Obrane or HVO). Another assisted in the formation of and served in institutional arrangements that were established to govern a portion of the Republika Srpska. Finally, others served in judicial leadership positions within the transitional government and quasi-governmental

26. See $\S \S \mathrm{IV}$, and $\mathrm{V}$ and Appendices $\mathrm{D}$ and $\mathrm{E}$. 
structures between 1992 and 1995. While these participants described their involvement or action in support of political parties during the war, none identified their activities as political.

Under current law, judges and prosecutors are prohibited from membership in political parties. Participants supported this rule and agreed that political involvement might compromise the objectivity of a judge or prosecutor. As one participant stated: "If you become a member of a political party, it's a matter of time before you become an object of manipulation." Participants stated that currently they were not politically active. Only one participant expressed any personal sympathy for a particular political party.

Participants deplored being targets of political influence and many felt that the independence of judges and prosecutors was undermined by the power that political parties exerted on the judicial system. One participant observed: "the judicial system is in the hands of the political oligarchy" and said, "as long as the people who are guilty and responsible for the war remain in positions of power, there will never be an adequate application of the law the way we want." A few participants stated that politicians did not want a truly independent judiciary because it did not benefit them: "Politicians don't care about us, to have the rule of law, an independent judicial system, because if these existed they could not do what they wanted to do." Some participants specifically commented on politicians' lack of education and capability. One legal professional derisively remarked that he thought a top local official "did not finish college."

Many participants often spoke emphatically about their resistance to attempts at political interference and their own resolve to apply the law. "I can certainly vouch that this court does all the things in a very professional manner. But I do have information that in other parts of the country, nationality of a party sometimes matters. But I cannot speak about that, it's just what I heard." Another stated his resolve to remain impartial: "You're always under some influence from the politics, the politicians, the parties. And we are here to be professionals, to proceed according to the law as it should be and that's difficult and hard."

Sources of pressure included government officials and international monitors. "If there is political pressure, it's coming from the cantonal or federal ministry of justice - someone who is in the government." A judge stated that he felt international monitors had sought to influence him improperly by suggesting at the close of a proceeding, but prior to the verdict, that the evidence was insufficient to convict and the judge should release the accused. Another form of political pressure cited by others was the failure of Ministry of Justice officials to support the judiciary after nationalist groups or the international community criticized Bosnian judges.

Participants specifically cited control of the legislature over judicial budgets as an essential factor that contributes to political interference in judicial matters. Many tied financial dependence to corruption. One participant observed that since the judicial budget is controlled by the legislators "of course, they can affect the work of the court." 


\section{Attitudes Towards the International Community}

On the whole, study participants used the term "international community" broadly to refer to the United Nations, foreign governments and international governmental and non-governmental organizations. This terminology reflected a homogenization of foreign actors as well as a recognition of the power differential between Bosnian nationals and representatives from foreign-based organizations. Generally, participants expressed ambivalence toward the involvement of the international community in $\mathrm{BiH}$. On the one hand, participants welcomed the role of international institutions and organizations in strengthening Bosnian governmental structures and promoting economic growth. On the other hand, they often perceived the manner in which those interventions took place to be demeaning.

Participants in each national group agreed that involvement of the international community was necessary to prevent further war, to stimulate the economy, to ensure fairness and accountability in judicial proceedings and to prosecute war criminals. Some expressed concern that in the case of national war crimes trials, judges in Bosnia might be biased or politically pressured to render a particular verdict.

Citing political pressures, participants also favored international involvement to promote an independent judicial system. In particular, participants supported the efforts of groups like OHR to secure enactment of legislation to promote the independence of the Bosnian judiciary. However, some prosecutors expressed concerns that not enough international attention had been paid to the need to strengthen prosecutorial independence and suggested that broader powers for prosecutors should be included in the criminal code.

Participants expressed mixed reactions to the legal training for judges and prosecutors provided by international organizations. Many reported that the training was not well planned, that those conducting sessions were not familiar with Bosnian legal structures and that the training covered too many topics in a limited time. One stated: "You cannot expect a seminar to be organized and in two days to know all European laws." Some reported that international seminars were not particularly relevant to their work because the trainers and attendees frequently came from different legal systems.

However, other participants noted that the value of the seminars lay less in their content than in the opportunity to renew contacts with colleagues across national lines. Judges and prosecutors reported sporadic communication with colleagues outside their area and welcomed the opportunity to reestablish professional relationships in the other entity. One participant who attended an international seminar noted its main significance as "the first meeting of judges and prosecutors from all around Bosnia-Herzegovina." Participants considered selection to participate in such meetings a professional distinction and some raised the concern that the selection process for the seminars was not transparent. 
Participants expressed criticism of international organizations operating within Bosnia. Opinions varied toward international organizations such as OHR, United Nations and the ICTY ${ }^{27}$ as well as international non-governmental organizations. Participants frequently commented that the representatives of international organizations lacked knowledge about Bosnia and seemed unprepared and uncommitted. One participant described international monitors as people without "good wishes" who were only interested in living in a foreign country for awhile. Another experienced as personally adversarial the comments of an international monitor who also was a judge: "He wanted to irritate me." This same judge described his other experiences with international visitors to his courtroom as pointless "because all trials in Bosnia are public. I was curious why they came. It's of little value."

Some participants perceived international involvement in Bosnia as an unwelcome intrusion into the country's legal system. One participant stated that he would prefer that the international community focus on assisting Bosnia in creating its own institutions rather than intervening in routine matters. Another reported that the representatives of international community within Bosnia lacked knowledge of, and respect for, the Bosnian legal system and he complained that he had to spend "half my time explaining basic laws and rules we apply here, sometimes it's boring."

In particular, participants expressed positive and negative attitudes toward OHR. Some viewed it as a thoroughly political institution and expressed frustration with OHR's changing of the laws. Nevertheless, many felt that OHR ensured political stability. One participant who criticized certain OHR actions also noted that without it "we would still be arguing about the size of the letters on passports." Another attributed judicial independence to OHR, stating:

Fortunately we do have the OHR, which is the only body in this region that can say: "Hey, prosecutor, you are not a good prosecutor, you have done such and such." Without OHR, you would have totally dependent judges and prosecutors, because the political parties would want to make agreements and that would make judges and prosecutors dependent.

Two Bosniak participants were appalled by the comments made by the UN Special Representative in Bosnia, Elizabeth Rehn, in which she criticized the judiciary as corrupt. ${ }^{28}$ These judges felt that Rehn's blanket criticisms unfairly damaged the credibility of the judiciary. "Mrs. Rehn openly said that the courts are corrupt. I don't think that she talks for nothing. But it would be good if she could offer concrete evidence. There are many good judges who are far from that categorization." The other judge asserted that such comments put an "enormous burden on all judges" since the judicial system was unable to initiate removal proceedings without allegations against specific judges, and thus the accusations encouraged those dissatisfied with a court judgment to claim it was the result of corruption.

27. The opinions regarding the ICTY are addressed separately, in $\S \mathrm{IV}(\mathrm{C})$, below.

28. See supra note 14. 


\section{National Consciousness and Allegiance to State Structures}

Although self-identification with a national group contributed significantly to participants' national consciousness, e.g., "I am Serb, I cannot be anything else," or, "I am a Bosniak. Because I feel that way," many participants expressed the idea that nationalism is anathema to the legal profession. As one participant noted, legal professionals "are not burdened with national tensions, or they shouldn't be." Some participants suggested that they, as professionals, combated tensions between national groups and did not contribute to the war: "We judges are professionals, and we did not cause this conflict."

Nonetheless, the theme of national identity, citizenship and allegiance was evident in the interviews. Participants' attitudes toward national identity were influenced by their political views. One participant expressed regret at no longer having the option to identify as a "Yugoslav." Another spoke nostalgically about the time before the war when one's identification with a national group was a private matter. A Bosnian Croat participant expressed his view with a caustic comment regarding the "so-called Herceg-Bosna" State. Other Bosnian Croat participants however, referred to the army of Bosnia-Herzegovina during the war as the "so-called BiH Army." A Bosniak participant reflected on the impact the war has had on national consciousness: "Well, before the war . . Bosnian people were the people that were Yugoslavs. Because we felt Yugoslavia was our country. ... [W] had different identifications with national groups, and it was less important which group you were in .... [T]hat wasn't important before."

Participants spoke at great length about issues regarding the role of the State, the question of national boundaries and allegiance to State structures. Their responses revealed ambivalence towards the Dayton Agreement and its consequences for the country. These perceptions appeared to be influenced by membership in a particular national group. Therefore, we examine these responses according to the region of the country in which the participant was interviewed.

Many participants were grappling with how to reconcile nationalism with the political structures established by the Dayton Agreement. One Bosnian Croat participant discussed the relationship of the constitutions to reconstruction and reconciliation and noted: "In no State do you have two entities, three nations, four constitutions, cantonal constitutions. How can you realize the rights? It is a forest of rules that no expert can go around in." Two other participants believed that the constitutions adversely affected the rights of national minorities in Bosnia. One stated with respect to minorities such as Hungarians: "The constitution does not guarantee rights to all nations, which needs to be changed." The other observed: "I know my friends, Serbs who are natives of Sarajevo, and they feel not as a minority but as second class citizens in the territory of the Federation. They don't feel comfortable in such a legal system."

National divisions were noteworthy among the responses to questions regarding the supreme law of Bosnia and whether a Supreme Court of BiH should 
be created. The Dayton Agreement established that the constitution of the State, which was an annex to the Agreement, was the supreme law of the country. Virtually all Bosniak participants reported that the Constitution of the State of Bosnia and Herzegovina was the highest source of legal authority, while virtually all Bosnian Serb participants stated that the highest authority was the Constitution of the Republika Srpska or both the constitutions of Bosnia and Herzegovina and the Republika Srpska. Only one Bosnian Serb legal professional stated unequivocally that the Constitution of Bosnia and Herzegovina was the supreme law of the land. The answers of Bosnian Croat participants were divided between the State constitution and Federation constitution. ${ }^{29}$

Responses similarly were divided regarding the need for a State Supreme Court with jurisdiction to hear disputes involving State laws. Currently there is no court with the ability to adjudicate such matters. ${ }^{30}$ Bosniak legal professionals uniformly supported this proposal, while with two exceptions, Bosnian Serb participants opposed it. Bosnian Croat participants were ambivalent and gave the proposal qualified approval. ${ }^{31}$

In general, Sarajevo Group participants (including non-Bosniaks) expressed the desire for the re-creation of a unified and diverse Bosnia. This sentiment was illustrated by one judge who described pre-war Bosnia as a country in which "people lived together for thousands, thousands of years" and thirty percent of marriages in Sarajevo were mixed. Another spoke passionately about his beliefs in a diverse Bosnia: "Bosnia is . . . her structure, by her nature, she is really multi, multi, multi. And always we cared about that and now we also do care. And is has to be that way in Bosnia. But if it's not so then we have a problem."

Mostar Group participants were tentative in their support of a unified State. Eight qualified their opinion that it would be possible for people of different national groups to live together by noting that because of the war it would take time to achieve a multi-national state. As one described: "I think that it is possible, provided punishment of war criminals and the organization of a state, a normal state, not what we have now." Another who stated that life together was possible qualified his statement by noting that the pre-war political parties that initiated this "horrible war" remained in power. Thus, there was "no more trust" that the political process would result in normalization of relationships across national lines. However, one participant who agreed that Bosnians could live together so long as the international community was present, also advocated the further division of $\mathrm{BiH}$ : "I think that there should be three entities ... . Rela-

29. For a comparison by national group of responses to the question: "What do you consider the highest law of the land?" see Appendix C.

30. The BiH Constitution does not provide for any court of general jurisdiction at the State level. The primary function of the Constitutional Court is to adjudicate disputes regarding whether entity laws violate the BiH constitution. Art. IV (3)(a). Thus, there is no State court with jurisdiction for individual violations of State laws. See ICG Report Rule Over Law, supra note 15.

31. For a comparison by national group of responses to the question: "Should a Supreme Court of Bosnia-Herzegovina be created?" see Appendix D. 
tions between people would be much cleaner." Another participants said people could live "side by side," but that life together "all mixed up" was impossible.

Six Bosnian Serb participants stated that life together was possible, but their answers ranged from qualified support to outright skepticism. They said that the process would take time. As one stated: "It is possible, but we have to take time, lots of time. Hopefully life will be as it used to be. But I think that lots of time should pass." One participant stated that life next to one another was possible, but also circumscribed his answer:

It's possible to create conditions, to live peacefully one beside each other, one next to each other. And to agree and solve what is common to us, and mutual to us. And to get used to it in the course of time. To change people and politics because if we could live for seventy years in Yugoslavia all together, why can't we live 1000 next to each other. But the international community contributed to all that because of their interfering with the conflict.

Two from this group of Bosnian Serb participants, while suggesting that life together might be possible in concept, noted that a unified state was impossible to achieve through external pressure. One stated: "There are a lot of common things between both of these entities" but continued that life together was not possible "if we are forced." The other discussed the challenges of refugee returns, both on a practical and a political level, and stated that it might not be practicable to implement the right of return guaranteed in the Dayton Accords given the horrors that people experienced during the war. Finally, two stated that life together was not possible. As one put it:

It is a problem of the antagonism between Christianity and those other ones, between all three parties. The differences are too high, too great, the best solution is this one, one living next to the other for the future of children that are to be born. Who will guarantee that if we are living mixed that there would not be a war again?

It was significant that despite the variety of and often-contradictory statements among participants regarding national identity, there appeared to be a consensus among all participants that any continuation of war would be the worst thing to happen to $\mathrm{BiH}$. As captured by one participant: "I am conscious that war cannot bring good to anyone. And war is the worst evil that can happen to people. Nothing can be worse than that." Another legal professional reflected on the lasting impact of the war on the judiciary:

We have lived through a hard period, three or four years is a lot for an individual; for a nation it is only a moment. You have to understand that our judicial decisions are still connected to war, but I think that things have improved, people are and will learn about the consequences of war and everything that happened during the war. Every war is evil, and this one that took place here [was as well], however, regardless of things I am hopeful.

\section{B. Factors That Contribute to Resistance Among Participants to International Criminal Trials and Accountability for War Crimes}

Several factors emerged that contributed to reluctance of these Bosnian legal professionals to support the work of the ICTY wholeheartedly. While many accepted the Tribunal in concept, participants generally lacked clarity about its 
goals. In particular, the responses of Bosnian Serb and Bosnian Croat participants indicated they did not share the goals of the ICTY as they understood them. The Security Council resolution creating the ICTY, ${ }^{32}$ and subsequent annual reports ${ }^{33}$ reflect the goal of the international community to create a judicial body to hold accountable those responsible for war atrocities and to promote a "sustainable peace" among the peoples of the former Yugoslavia. The participants were asked specifically on whom the ICTY should focus and whether a connection existed between the work of the ICTY and the processes of social reconstruction and reconciliation. The responses indicated a lack of consensus among participants of the differing national groups as well as within national groups. In addition, there was a gap between the expectations of Bosnian legal professionals and the goals of the international community.

Further, proximity to violence and physical destruction of the community exerted a critical influence. Participants from areas untouched by the fighting, primarily Bosnian Croats, were prepared to put the past behind them. They focused on economic reconstruction as a mechanism for social reconstruction and less on the contribution of war crimes trials to this process. In marked contrast, those participants who lived in areas of heavy fighting emphasized the atrocities of the war and questions of individual responsibility and accountability.

There was a divergence of opinion as to who was responsible for the war and who should be held accountable. This divergence was also reflected in differing opinions about individual and collective responsibility and accountability for war crimes and genocide. ${ }^{34}$ However, at least one participant in all three national groups identified the international community as responsible for the war. They believed that the world community did nothing to stop the war, even after atrocities were discovered, resulting in an extended conflict.

Nevertheless, the divergence of perspectives regarding responsibility and accountability for the war was largely consistent among participants of the same national group. However, the views of Bosniak, Bosnian Serb and Bosnian Croat legal professionals on these topics were inconsistent among the groups and often contradictory. Since three different versions of these themes emerged,

32. See supra note 4.

33. Report of the International Tribunal for the Prosecution of Persons Responsible for Serious Violations of International Humanitarian Law Committed in the Territory of the Former Yugoslavia Since 1991, U.N. GAOR, 54th Sess., Agenda Item 53 at 3, U.N. Doc. A/54/187; See also: Fifth Annual Report of the International Tribunal for the Prosecution of Persons Responsible for Serious Violations of Intemational Humanitarian Law Committed in the Territory of the Former Yugoslavia Since 1991, <http:www.un.org/icty/rapportan/rapport5-e.htm>; Third Annual Report of the International Tribunal for the Prosecution of Persons Responsible for Serious Violations of International Humanitarian Law Committed in the Territory of the Former Yugoslavia Since 1991, <http:www.un.org/icty/rapportan/thir96tc.htm>; First Annual Report of the International Tribunal for the Prosecution of Persons Responsible for Serious Violations of International Humanitarian Law Committed in the Territory of the Former Yugoslavia Since 1991, <http:www.un.org/icty/rapportan/first-94.htm>.

34. A comparison of the responses by national group to the question: "In your legal opinion, did genocide happen anywhere in Bosnia-Herzegovina? Against whom did these acts of genocide occur?" are contained in Appendix E. 
we will describe separately how each of these perspectives influenced resistance to the ICTY.

Finally, participants reported misunderstanding regarding and disagreement with the decisions by the international community regarding the location of the ICTY as well as the rules of evidence and procedure governing its work.

\section{The Bosniak Perspective}

All Sarajevo Group participants stated that Bosniaks were the victims of Serb aggression. They identified Slobodan Milošević, president of Yugoslavia and Radovan Karadžić, former president of the self-proclaimed Bosnian Serb Republic as those responsible for the war. Two of the Sarajevo Group - both of whom lived in areas of heavy fighting between Bosniak and Bosnian Croat forces - included Croatia as a belligerent state, and specifically named Franjo Tuđman, now-deceased president of Croatia, as the initiator of these actions. One participant reinforced the notion of individual accountability as follows:

Believe me that I am telling you what I feel because I was here during the war and I survived with my family .... And I am telling you now as a human that people responsible, accountable and guilty for all those crimes should be accountable for those crimes, because people need that.

Half of the Sarajevo Group focused on the events in Srebrenica as epitomizing the aggression against, and genocide of, the Bosniaks. For example, one participant, when asked against whom genocide occurred stated: "We all know and considering Srebrenica, and starting with Srebrenica, we all know against whom." Another stated:

If you start from the definition of genocide used by The Hague Tribunal I think that in relation to Bosniaks the genocide did happen, especially in certain parts. Especially in thinking about the Podrinje, because the Muslims - Bosniaks - were a majority in all the municipalities before the war there except in Foća. And in Foca there was a really slight majority of Serbs in relation to Bosniaks. And the war was conducted there; you had civilians, the destruction of whole Islamic monuments, mosques, mass killings of people, showing that the real goal of this was ethnic cleansing, actually, genocide. The identical of this situation was in the [Bosnian] Krajina, region.

Two Sarajevo Group participants stated that the Bosnian Croats were also victims of genocide, while one participant stated that "genocide occurred on all three sides" and another alluded to "genocide in a couple of directions."

Nearly all Sarajevo Group participants believed that there should be differing accountability for those in command responsibility and those in lower positions. They affirmed that those in command positions should be held accountable for the acts of their subordinates and cited specific examples from the ICTY trials or war anecdotes.

Sarajevo Group participants believed that the ICTY was a neutral and fair court in which to try indicted war criminals, especially those of highest rank. No one described the work of the ICTY - including the selection of indictees as "political." All affirmed their support for its existence, while recognizing the challenges that it faced. As one stated: "I think that the ICTY is very correct. I 
know it has some difficulties, some technical problems. . . I am for that court to be stronger and to be permanent." Another felt that those who critiqued the work of ICTY did so from a nationalist perspective: "All complaints about the work of the ICTY are mostly of a political nature. . . I w want it to work, and to try everybody, not just certain people." Most of the Sarajevo Group participants agreed with one judge who stated that he believed the "ICTY is rooted in justice."

Many Sarajevo Group participants believed that the main objective of the ICTY should be to prosecute and judge those individuals responsible for carrying out the war in Bosnia. They expressed a belief that the ICTY should focus its energies on those "most responsible" or "most guilty," and that the Tribunal would be more effective if this were done. However, three participants also expressed concern that the international community lacked the "political will" to arrest the "biggest fish."

Some Bosniak participants specifically expressed relief that the ICTY assumed jurisdiction for the cases involving the most serious war crimes. One stated that the trials of the "most accountable" war criminals, those who committed the most serious crimes and who still wield tremendous power, were the ones in which the involvement of the international community was most necessary. Another stated that despite the best intentions of a good judge, it would be difficult to conduct a fair trial of such cases in Bosnia because of political pressures. By the term "political pressure" he was referring specifically to inappropriate attempts at influence from various sources such as the Ministries of Justice, individual politicians, or criminal gangs. A Bosniak judge denied any "unprofessional" aspects of the judiciary but said the ICTY was needed because it used different "standards." In contrast to this view, another judge expressed his frustration with the ICTY and suggested that the Bosnian judiciary was better able to adjudicate war crimes trials: "The ICTY is still running away from genocide. And we who are here, we know why somebody was killed. Somebody was not killed because he was a civilian, he was killed because his last name belonged to a certain [national group]." Other than this critique, Bosniak participants saw the location of the ICTY as an advantage.

Sarajevo Group participants, in general, resisted assigning collective responsibility to "all Serbs" or "all Croats." Further, participants rejected the principle that an entire national group should be held accountable for the actions of their leaders. When asked specifically about accountability for war crimes, respondents stated that "those who organized the crimes should be held accountable" and tended to reject the assignment of accountability to anyone other than specific individuals.

Sometimes, these comments regarding collective accountability were tied to reconciliation in Bosnia. Sarajevo Group participants made a connection between trials of accused Serb war criminals and the alleviation of condemnation of the "whole people," as one participant stated:

I think that the trials like those can build some new relations between the people.

I think that is making a more clear situation between people. If he is guilty he 
should be responsible for those acts. So less the whole culture be suspected for the one man's act. Every criminal act is done by an individual or many of them in a group. But never a people, whichever it is. Some punishment for those crimes can bring reconciliation and normal life in Bosnia.

Another echoed this belief, stating:

I think there is no making up without punishing the guilty. I think it is very important that nobody's guilt is collective guilt, every guilt is individual. And because of the removing the burden of collective guilt, meaning for example, the guilt of the Serbian people, it is in their interest that accused war criminals from their ranks be punished so it is known that not the whole people as it happened committed the war crimes. And the same of course applies to the other two peoples.

The belief that reconciliation and reconstruction depended upon the successful prosecution of war criminals is most characteristic of the Sarajevo Group. Some Bosniak judges felt that the ICTY contributed to reconciliation because it lay outside the influence of domestic political structures. Some of these participants saw value in the international community's ability to name perpetrators of war crimes and to facilitate discussion of the war in Bosnia. Many thought that the prosecution of war criminals by the ICTY would contribute to reconciliation in Bosnia. Others, however, suggested that even if the ICTY did not facilitate reconciliation it served to acknowledge their status as victims in the war. Some judges said that the longer the major war criminals such as Karadžić and General Ratko Mladić, former head of the Bosnian Serb forces - remained free, the less likely reconciliation would result from their eventual prosecution. As one judge indicated, the faster the resolution of these significant cases, the more their outcome would contribute to the process of reconciliation.

\section{The Bosnian Serb Perspective}

Universally, Bosnian Serb participants viewed the conflict as a civil war; while only three specifically referred to the war as a "civil war," none referred to it as a war of aggression or an international war. As one participant stated: "Here in Republika Srpska, we consider that it was a civil war. The other side thinks we were aggressors. How can we be aggressors in our own country?" One participant stated that the Bosnian Serbs fought to maintain Yugoslavia as a unified state and to "prevent a centralized state [in Bosnia] where one nationality would be dominant." Another participant unequivocally stated: "This was a religious civil war." This perspective contrasts sharply with that of participants of other national groups.

Dominant themes in the Banja Luka Group were that the onset of the war was inevitable, inexplicable, or that the war was due to factors beyond the control of Bosnian Serbs. "The war just had to happen. As soon as the break up of Yugoslavia took place, Bosnia-Herzegovina could not stay intact. The war was inflicted upon the Serbs. There was no aggression from any side." Two Bosnian Serb participants stated that they could not attribute responsibility for the war to anyone in particular. As one put it, this was "because we do not know 
the background of the war itself, or the real cause of all this." Participants framed their understanding of the consequences of the war in terms of inexplicable events. For example, one participant termed the loss of the Muslim population in the area as "migration." He wondered what had happened to his legal colleagues: "Many of them I cannot even say where they are now. Some of them were just gone when the war happened. Many abandoned these areas. Some citizens from this area left."

Four of the nine Bosnian Serb participants stated that they did not believe or did not have sufficient evidence to confirm that genocide occurred during the conflict. "Did genocide happen? I think not. I am not aware of those facts." Or as another stated: "I don't have any evidence and information whether it happened. In our area, I have no information." Four observed that genocide was carried out by all three sides. As one remarked: "It happened throughout Bosnia. ... To all three peoples." One legal professional declined to respond.

For the most part, Bosnian Serb participants did not assign responsibility to specific individuals for initiating the war. Rather, they assigned responsibility to larger categories, including "the people," the international community, politicians and national parties. Others responded by saying that they did not know, refusing to answer or as noted above, that the war was inevitable.

Like their Bosniak and Bosnian Croat colleagues, Bosnian Serb participants emphasized individual accountability for all who committed war crimes. As one participant stated: "I chase criminals" regardless of nationality. Another emphasized that "a war crime is a war crime no matter from which side it arises." Seven of the participants were asked specifically about command responsibility; of those, four acknowledged that commanders should be held accountable for the actions of their subordinates. Only one participant mentioned a specific individual - General Tihomir Blaškici ${ }^{35}$ when discussing this concept. This lack of specificity mirrored responses to the question of accountability for the war for which participants named no individuals. Those who discussed this topic emphasized not rank, but bringing to justice anyone who committed war crimes.

Along with Bosniak and Bosnian Croat legal professionals, Bosnian Serb participants rejected the concept of collective accountability for war crimes. In contrast to their resistance to holding individuals responsible for the war, Bosnian Serb participants insisted that only individuals could be held accountable for war crimes. In discussing genocide, one participant stated that "genocide was done by individuals or small groups of individuals, not by a whole nation." However, even here, some participants also rejected the principle of collective responsibility of political leaders. While one Bosniak and a few Bosnian Croat

35. On March 3, 2000, Blaškić was sentenced by the ICTY after the court found him guilty crimes against humanity, war crimes and grave breaches of the Geneva Convention of 1949. The sentenced followed a 25 -month trial with testimony from 158 witnesses and approximately 30,000 pages of evidence. Blaškić, 39, was commander of Croat fighters in central Bosnia during the war. He was held responsible for attacks across the Lasva River Valley that left hundreds of Bosniaks dead and sent thousands more fleeing the area. In particular, the court held that Blaškić ordered a April 1993 attack on the village of Ahmici in which more than 100 men, women and children were killed. 
participants were willing to hold political leaders accountable for the war - including their own - Bosnian Serb participants were unwilling specifically to name Bosnian Serb political leaders among those responsible for the war. In fact, two participants stated that political leaders should not be held accountable because their policies reflected the will of the people. While some did blame the war on politicians, none named specific leaders of any national group, and one specifically stated that Milošević wasn't "guilty."

While few Bosnian Serb participants mentioned the international community in connection with the war in Bosnia, those who did were vehement in their opinions. Generally, they believed that the international community was unfair to the Serbs or that it did not understand what happened in Bosnia during the war. One participant characterized the opinion of Serbs by the international community as: "Serbs are the bad guys. But I think it's the reverse." This sentiment was echoed by another: "We are satanized in the world, and we are not like they said, we are an old Christian, civilized people. We are not the monsters we are presented in the media." Another participant stated: "It seems to me that many representatives of international organizations, a great number of them, are always in a trance. Maybe there wasn't an opportunity for them to learn, or maybe they gained their information from different sources, about what really happened here."

Three Bosnian Serb participants saw the actions of the international community toward them as hypocritical and openly expressed hostility toward NATO bombing of Serbia and Kosovo. They complained about the "double standard" of accountability - Bosnian Serbs were being held accountable for war crimes committed in Bosnia, while leaders of countries participating in the bombing were not held accountable although these Bosnian Serb participants saw the bombing as a violation of international law. One referenced the United States bombings of Yugoslavia and Vietnam to illustrate the hypocrisy of the international community. The other two participants supported this concept by pointing out that NATO had violated the principle of state sovereignty by initiating the bombing of Serbia.

Using this same argument, Bosnian Serb participants were highly critical of the ICTY. Many disparaged the ICTY for its apparent lack of impartiality and independence, qualities that underlie their definition of professionalism. As one participant stated: "I think that court is not a real court. I think that my court is more mature in its proceedings, and more expert and diligent in the conduct of trials." All criticized the ICTY and international organizations operating within Bosnia for being influenced by politics. "The international court in The Hague is discussed too much. It is too artificial a court and it is under the jurisdiction of powerful societies. There is no justice in that court." In addition, many stated that they did not understand the court and its workings because it is "nothing like a court we have here." The one Bosnian Serb who supported the ICTY suggested that it should "organize a round table for every judge and prosecutor who is willing to come to meet and to get familiar with The Hague Tribunal. ... 
To have an explanation why it is good for someone and not for someone else [to be indicted]. Not to be closed."

In general, participants viewed the Tribunal as a political body that was an instrument of Western influence rather than an independent judicial institution. One Bosnian Serb participant asserted that public international law has no place in courts because it concerns violations by states of their international obligations rather than individual liability. Two participants pointed to the fact that only Western judges served on the Tribunal and that no judges from the national group of the accused sat in judgment of their own.

When Bosnian Serb judges and prosecutors were asked on whom the ICTY should focus its energy, the responses were general in nature. Almost universally, they stated that the ICTY should deal with "all of those who committed war crimes" or that "all should be held accountable." When asked how the ICTY should allocate its scarce resources, participants reiterated their initial responses. For example, one Bosnian Serb judge stated: "I would choose the persons who committed war crimes." When asked to be more specific, this judge took out the Criminal Code of the Republika Srpska and proceeded to show the interviewers the provision regarding war crimes. Another participant, when asked whether the ICTY should focus on leaders, such as Milošević, responded: "I won't answer. On the persons, that's politics, and I don't want to interfere with that topic. I think that my answer is sufficient, that everyone who committed a war crime should be tried." However, one Bosnian Serb judge explicitly stated that the ICTY should focus "on those who established . . . the conditions for the war."

Many participants expressed the view that the ICTY was biased against the Serb people. Six Bosnian Serb participants stated that the ICTY only targets Serbs or that the actions of the ICTY are only focused on "one people." As one participant described: "There are some rules created in [the] world that only Serbs are criminals." In addition, two specifically mentioned that, during the course of a NATO Stability Force (hereinafter SFOR) action to arrest the former Prijedor police chief, he was killed. They described the SFOR arrest as a kidnapping and they saw this as a flagrant disregard of the judicial process. Three felt that there was "no justice" or "no righteousness" in the ICTY. Another participant raised the example of the linkage between economic assistance and cooperation with the ICTY as additional evidence for the politicization of the ICTY. Paradoxically, while all but one of the Bosnian Serb legal professionals criticized the ICTY as unfair, only two believed that it should be abolished.

Bosnian Serb participants were dubious about the impact of the ICTY on social reconstruction. Six stated that they did not believe that the ICTY and the process of social reconstruction were linked. Participants illustrated their lack of confidence in the ICTY's contribution to social reconstruction by noting 'the future of the people in this area is not dependent upon the ICTY. The ICTY is not significant for the life of those people here." One participant, who was particularly vehement in this view, reasoned from his own feelings about the impact that the successful prosecution of those who burned down his house would have 
on him: "It would not change [my feelings about social reconstruction]. I don't have any hope for [a multi-ethnic state] actually happening. If they were caught and tried I would have no satisfaction in that." The five other participants stated that the ICTY played no role in reconstruction because reconciliation was an extra-judicial process: "When someone wants to forgive somebody, he'll do it without a court. ... The fate of those people here is not a matter of nationality or interest, it is not dependent upon some court. ... If we are human, we don't need a court."

In fact, two Bosnian Serbs suggested that the ICTY and its slowness and inefficiency might be widening the gap between the peoples in Bosnia. Another described this belief more starkly, stating that the ICTY had a negative influence upon people and increased the "antagonism" between them. However, two others believed that the ICTY could, if it were more "efficient and fair," contribute to the process of reconciliation. Another stressed that it would take time to overcome their mistrust of the ICTY: "Maybe we're still under the influence of the war." Finally, one felt that economic development, and not the ICTY, would trigger social reconstruction.

Bosnian Serb participants were resistant to the Tribunal and to its primary jurisdiction for war crimes. According to the Rome Agreement, Bosnian prosecutors must seek permission from the ICTY before initiating arrest and prosecution of war criminals. Although the Bosnian Serb participants did not explicitly comment on the location of the Tribunal, nearly all stated that they did not see why war crimes trials could not be held in Bosnia. One participant suggested that the ICTY conduct its proceedings in Bosnia. Eight Bosnian Serb participants believed that national courts were competent to conduct trials of accused war criminals. Of this group, two believed that the trials should only be held in the areas where the crimes were committed. Two implied that national courts were on par with the ICTY and could conduct fair trials, but one suggested that it would be good for internationals to conduct trials in Bosnia.

\section{The Bosnian Croat Perspective}

Virtually all Mostar Group participants perceived the war as an act of the Yugoslavian People's Army (hereinafter Jugoslovenska Narodna Armija or JNA) and Serb aggression, and many specifically named Milošević and Karadžić as responsible. As one stated: "The politics of Slobodan Milošević and Serb nationalism, those started the war, others just accepted it." Mostar Group participants did not differentiate between the Yugoslav national army and the Bosnian Serb forces. "In Bosnia-Herzegovina there was Serbian aggression by Serbia and Montenegro." Another participant assigned responsibility for the war by sharing an anecdote. Prior to the war, he was in Serbia on business and saw on a kiosk a map that appeared to show Yugoslavia. On closer inspection, the map was labeled "Greater Serbia" and much of Bosnia was included in this territory. Another stated: "I think it was the policy of Slobodan Milošević. He did not understand that these countries could separate peacefully." Finally, another described the events leading up to the war: "We all voted on two options. 
Becoming a state or staying in Yugoslavia. We voted for independence of Bosnia-Herzegovina. The Serbs would not abide by such decisions and so they started the war."

Many participants stated that the actions of the HVO were simply a response to the aggression of the Serbs and that the Bosnian Croats were the only ones who were ready to defend themselves:

There were many victims except on the Croat side because people prepared to defend themselves.... Herzegovina knew what would happen because they saw an example of it in Croatia. The Croats in Herzegovina stopped the Serbs. While Croats were fighting the Serbs who were trying to capture Konjic, the Muslims were sitting in the cafes.

Although Bosnian Croat participants did not specifically discuss the alleged atrocities committed by the HVO, they defended their tactics by asserting that every party to the conflict, including the HVO, needed to "play by the Serbs' rules" and thus followed the lead of the Bosnian Serb forces.

Six Bosnian Croat participants stated that genocide occurred against all three peoples in Bosnia. One stated that the JNA/Serb aggression against the Bosniaks and Croats was an act of genocide; however genocide by the other sides was not as clear-cut. One Bosnian Croat judge explicitly acknowledged that Croat forces committed genocide, stating: "Genocide took place on all sides. But, as Croats, there are fewer Croat perpetrators but it seems as though they are the ones that are caught. But that does not undermine the percent of responsibility, their accountability, the very numbers are the evidence." Other participants had different views: "I don't think there was a real genocide anywhere in Bosnia-Herzegovina. In some ways there was a genocide, in others not actually, you didn't have one nation actually completely wiped out." One Bosnian Croat refused to answer the question. Interestingly, none of the Mostar Group participants talked about the collective accountability of any of the national groups involved in the war.

Mostar Group legal professionals adhered to the concept of individual accountability. However, their acceptance of the principle of command responsibility was more ambiguous. As an example, two Bosnian Croat judges referred specifically to the Blaškić trial and expressed skepticism about his control of the forces under his command. In contrast to this view, one participant believed in the application of command responsibility. "Because it is difficult to establish who murdered, the commanders of military units that did commit these crimes should be responsible, should be accountable." The lack of clarity around this issue was illustrated by a statement made by another Bosnian Croat judge. He claimed that in order to determine responsibility for war crimes, one needs to ascertain who was in control of the geographic region at the time. This contradicted his earlier statement questioning the concept of command responsibility.

Like their colleagues in the Sarajevo Group, Bosnian Croat participants expressed concerns regarding the acquiescence of the international community in the face of atrocities. As one Bosnian Croat observed: "If the international community wanted to prevent the wars, they would have prevented it. In 1992, 
in 1991." Another pointed to the international arms embargo: "When BosniaHerzegovina was attacked, the international community imposed an embargo and allowed the Serbs to kill some three or four hundreds of thousands of people so the international community is directly responsible for it." Finally, one Bosnian Croat participant went so far as to suggest that the Dutch battalion in Srebrenica should be held accountable for the massacre of Bosniaks there.

Several Bosnian Croat participants also criticized the ICTY and international organizations operating within Bosnia as thoroughly political bodies. And one participant criticized the Federation's choice of liaison to the ICTY as politically motivated and unrepresentative of the interests of Bosnian Croats. A third described the international community as following its own agenda, yet working to promote fairness and accountability in the domestic judiciary.

Mostar Group participants had specific ideas regarding how the ICTY should focus its resources. Many argued that the ICTY should indict and try those of the highest rank, specifically Karadžić, Mladić and Milošević. A common theme among Bosnian Croat participants, frequently associated with an expression of frustration or anger, was the belief that only Croats were held in custody in The Hague. Although they never explicitly denied the culpability of Bosnian Croat indictees, many expressed concern that no indictments had been issued by the ICTY for atrocities committed in pre-war Croat-majority towns: "I think you know that no one from the army of Bosnia and Herzegovina is accused of crimes, only Croats. In places where the BiH Army operated, murders occurred, in Prusina, in Grabovica, and in Doljani. Nobody has answered for those crimes." Three participants referred to these murders and indicated that requests to arrest those involved had been sent to the ICTY in accordance with the Rules of the Road but no further action had resulted. Many of the Bosnian Croat participants expressed concern that the international community pressured Croatia to turn over its indictees or lose valuable economic assistance. However, one participant was pleased that the Croatian government had complied with ICTY requests to deliver Croatian accused war criminals to The Hague.

In addition to the criticism that Bosnian Croats were selectively prosecuted by the ICTY, participants reported concern about the way in which cases sent by Bosnian Croat authorities to the ICTY had been handled. These cases alleged war crimes against Bosnian Croats by members of the $\mathrm{BiH}$ army. When the ICTY returned the cases to Bosnia for trial, they were assigned to the Sarajevo Cantonal Court rather than the courts with original jurisdiction. Although the assignment of cases was not the responsibility of the ICTY, but rather that of the Federation Supreme Court, Bosnian Croat participants conflated these two mechanisms, assuming that the reassignment decision reflected the political priorities of the ICTY.

Bosnian Croat participants gave varied responses regarding the influence of the Tribunal in post-war Bosnia. Like Sarajevo Group participants, many believed that over time the work of the Tribunal could play an important role in reconciliation and reconstruction. As one participant stated: "I think that the ICTY is part of everything that has happened here," and that its work has al- 
lowed "people to talk about things more openly and more honestly." Still, two others expressly stated that the ICTY had no impact on reconciliation or reconstruction and that economic development was critical to a reconstructed society: "Our people care to buy medicine and to survive. That is the answer." Or as another participant stated: "I would not ever, personally, ever connect these ideas: social reconstruction, economic reconstruction, as far as I am concerned, they have nothing to do with those who committed war crimes." However, all believed - despite the reservations of some - that the ICTY and its work ultimately would be important to the country.

Like their counterparts among the Sarajevo Group, Mostar Group legal professionals questioned why more indictees had not been arrested and called for greater SFOR action. Many believed that the lack of arrests - especially of Bosnian Serb leaders - demonstrated a lack of political will on the part of the international community.

Similar to the Sarajevo Group, Mostar Group legal professionals believed that it was important for the ICTY to conduct its work in The Hague. Six participants stated that the trials should be held in The Hague, implying that judges in Bosnia would be subject to political pressures that would compromise their ability to guarantee fair trials. Two others proposed that the more important trials be held in The Hague while those of lesser rank be tried in national courts to speed up the process and reduce costs. In addition, participants believed that the country could not withstand the instability that would be a consequence of such trials.

However, some suggested that the ICTY would be more accessible to the people if it conducted trials in Bosnia, provided that international judges adjudicated the cases. Three expressed concerns that the location of the Tribunal was a hardship for the families of those awaiting trial in terms of the emotional burden, financial cost and the difficulty to meet with the attorney for their relative. Moreover, these same three participants were concerned that no compensation was paid to those acquitted by the ICTY. As one stated: "We have the situation where some people from the community, who have spent several months there, were actually freed in the end. I don't think it's fair that [they] do not have any right to compensation."

\section{Participants' Perceptions of Practices and Procedures of the ICTY}

Across national groups, participants generally lacked a clear understanding of the procedures of the ICTY. They expressed several areas of concern: its unique blend of civil and common law procedures; how cases are selected; how indictments are issued - particularly sealed indictments; the length of detention and trials; and the evidentiary rules applied by the ICTY.

Judges and prosecutors across national groups reported that they did not understand how the blend of common law and civil law traditions impacted the work of the ICTY. A Bosniak judge acknowledged that this structural hybrid made it difficult for judges in Bosnia to understand the procedures of the ICTY. As one Bosnian Croat judge stated: "None of us knows the rules according to 
which they work. Only a few people who have any contact with such a court know something about it, but the rest of us [do] not." In sum: "These rules are a bit foreign to us."

Participants also did not understand how the ICTY set priorities for investigations and prosecutions. Instances in which ICTY indictments did not conform to participants' expectations led them to conclude that the Tribunal and its processes were unfair. As one Bosniak judge explained his frustration with the process: "I can tell you that, as a citizen, if you have a United Nations resolution then you know who was the aggressor, then you can tell who is politically and militarily accountable, but probably the ICTY has its own way to work."

When asked about the practice of issuing sealed indictments, participants' responses fell into one of two categories. Bosnian Serb and some Bosnian Croat participants understood the practice of sealed indictments as a political tool to keep people "afraid" and to pressure politicians into desired behaviors, whereas most Bosniaks and many Bosnian Croat participants generally found the use of sealed indictments acceptable.

Bosnian Serb participants expressed concern that sealed indictments constituted an abuse of the indictee's rights, demonstrated the lack of transparency of the ICTY and were unnecessary. They asserted that war criminals could not evade justice forever. Another Bosnian Serb judge criticized the use of sealed indictments because he believed that innocent people would turn themselves in to the ICTY. However, he later noted that war criminals would not "accidentally run into SFOR soldiers." Finally, one judge noted that the lack of transparency in the indictment process creates fear among army veterans who worry that army service in this period might constitute a war crime.

Legal professionals in the Sarajevo Group generally found the sealed indictments acceptable. They recognized that under usual circumstances such procedures might violate the rights of the accused. However, in the present circumstances, they believed that the apprehension of serious war criminals warranted this deviation. One accepted the practice of sealed indictments as necessary because Bosnia was "totally undemocratic" and otherwise the capture of war criminals would be more difficult. Another stated that sufficient safeguards existed to make the use of sealed indictments acceptable. Finally, a Bosniak prosecutor saw them as necessary to bring those accused before the Tribunal. This prosecutor noted that if the procedures for sealed indictments were "written in their rules, that's okay."

Some Bosnian Croat participants echoed the views of their Bosnian Serb and Bosniak counterparts. Two stated that sealed indictments were necessary, at least temporarily: "It's okay if it will help to apprehend a criminal." Three others said that the sealed indictments were used by the ICTY "so they can manipulate" and maintain fear among the people. One Bosnian Croat prosecutor demonstrated ambivalence about sealed indictments by stating that they could be "justified" but "it is also about the political pressure."

While participants in the Sarajevo Group made no comments about pre-trial detentions, their colleagues complained that the detentions of accused war 
criminals were too lengthy. Across national groups participants decried the length of the ICTY trials. As one prosecutor noted: "Is it fair to keep someone waiting for four years if he's accused of war crimes, to keep him waiting for his verdict to be announced, guilty or not guilty? The Hague Tribunal has to be more efficient, and faster." When considering the ICTY trials, participants compared the length of trials at the ICTY with those conducted in $\mathrm{BiH}$, where criminal trials are generally shorter. They associated fair trials with speed and "efficiency" of the court process. "You can have justice if someone could be ... brought to trial in a very short time. Everything that has been dragged on has a negative effect. I am not saying that anybody should be amnestied because the time has passed, but I am saying the effectiveness of a sentence [is less]." Sarajevo Group participants echoed this concern.

Several participants criticized the efficiency of the ICTY. A Bosnian Serb participant remarked: "That's so much talk and fuss about [the ICTY] and little work done. They'll fill all those prisons and they're not doing anything." Many Bosnian Croat participants and one Bosniak specifically cited the multi-year trial of General Blaškić as an example of the excessive length of trials at the ICTY. When asked what the priorities of the ICTY should be given limited resources, a Mostar Group participant questioned the limited nature of the ICTY's resources in light of the length of the trials and number of witnesses called to testify.

In contrast, a Bosnian Croat judge averred that: "Justice may be slow, but it is available." And one judge who had visited the ICTY acknowledged the competence and diligence of the ICTY staff. However, he recognized that the Tribunal and its staff required time to understand the region, its history and the various political and military organizations. Similarly, one Bosnian Croat judge suggested that the ICTY has slowed itself down by accepting "small cases" rather than focusing on the most serious war crimes. This same judge supported others' concerns that the length of the trials was costly for defendants and their families, noting further that families turned to charitable organizations for financial support.

The use of expert witnesses by the ICTY provoked strong opinions among Mostar Group and Banja Luka Group participants. For example, one Bosnian Serb participant criticized the ICTY's reliance on an historian to determine the genesis of the conflict. This participant stated that he did not understand the relationship between such general information and a particular crime. He labeled expert testimony as "unreliable statements" that had "no relation" to a criminal case and concluded that the work of the ICTY involved "imagination." He reiterated that: "My job is based on the specific case, specific acts." He was supported by a Bosnian Serb colleague who stated that the ICTY "issued decisions without real evidence. I would never try a case like that."

Bosnian Croat participants also questioned the testimony of a history professor as an expert witness. As one noted: "He might never have been to Bosnia-Herzegovina. He was explaining the history of Bosnia, and the relationship between the three nations, which had nothing to do with the Blaškić case. But if judges want to know about Bosnia, they needed to educate themselves, like my- 
self: take books and read." Two Bosnian Croat judges asserted that only "direct" evidence of a particular crime should be admitted in court, as is the case in Bosnia.

On the other hand, only one Sarajevo Group participant commented upon the use of expert witnesses. This judge, who had visited the ICTY, looked more favorably upon the use of expert testimony and saw expert witnesses as advantageous because they were neutral, were not involved in the war, and offered "the highest scientific dignity."

The participants raised additional concerns about the quality and quantity of evidence. For example, a Bosnian Croat judge suggested that there should be more evidence at trial. Another viewed the release of evidence to the ICTY as dependent on internal political forces within Bosnia. In contrast, another Bosnian Croat legal professional felt that there were too many irrelevant witnesses called to testify in the Blaškić case: "There were two or three hundred witnesses there in The Hague who really didn't have anything to do with it, no connections with the case."

Four Bosnian Serb participants questioned the Tribunal's use of evidence. And others generally questioned the role of the ICTY in the collection of evidence within the RS.

\section{Participants' View of Their Treatment by the ICTY}

Across national groups, legal professionals perceived their sporadic contact with the ICTY as a sign of disrespect. Bosniak and Bosnian Croat judges and prosecutors reported periodic visits from ICTY officials to collect files regarding suspected war criminals. Those participants with experience presiding over or prosecuting domestic war crimes cases reported awareness of and compliance with the Rules of the Road procedures. However, ICTY officials failed to keep their Bosnian colleagues informed of the status of the investigations, even in response to direct inquiries. As one judge explained: "They came here at the end of 1995. They took the cases with them, and said that the criminals would be brought to justice, but nothing has happened." A judge reported that after having submitted twenty-five cases and waiting eight months, the ICTY had not responded. Other judges and prosecutors stated that they too had submitted files several years before and had received no communication. A Bosnian Serb participant expressed similar frustration. He reported that ICTY investigators never responded to an indictment he submitted for approval in mid-1997. These professionals viewed the ICTY as unresponsive and detrimental to the ability of Bosnian courts to conduct national war crimes trials.

Some who interacted with representatives of the ICTY wanted to be respected in their own right as legal professionals. However, their attitude toward the ICTY was ambivalent and influenced by the status they believed they occupied in relation to the international community. Participants across national groups reported they perceived that the international community saw them as intellectual inferiors who did not understand the relevant law. As one participant remarked: "When all these people come from outside they think that we 
absolutely do not have any knowledge; they have certain biases already when they come in." One judge remarked upon the power differential that exists between the ICTY and the Bosnian judicial system. However, one Bosnian Serb judge expressed pride in the approval by the ICTY of the legal work he had performed noting that: "Everything I did was accepted by the Tribunal with no objections." Even in instances in which the ICTY approved of their performance, the power of the Tribunal to validate Bosnian legal competence was clear.

\section{E. Gaps in Communication Identified by Participants}

With two exceptions, Bosnian legal professionals were poorly informed about the work of the ICTY. A Bosnian Serb participant questioned whether the Tribunal had ever issued a verdict. Another wondered whether it was founded on a statute. Some participants expressed concern that the information they had received had been distorted by the media. Despite this lack of information, participants did not report any self-initiated study of war crimes or the ICTY.

Legal professionals across national groups reported that virtually all the information about the ICTY they received came from the local sources. Participants in the RS and the Federation recognized that the limited source of information was problematic because of the nationalist slant of the communication industry in $\mathrm{BiH}$. One Bosnian Serb legal professional noted the influence of politics on media reports stating: "There is mostly news with political features, not professional." A Bosnian Croat participant stated: "Every side gets its own version of the story." A Bosniak prosecutor remarked that Bosnian newspapers were "short on news." Another criticized the accuracy of reporting about the ICTY, stating: "nothing can be lied about too much."

Across all national groups, participants desired impartial information about the ICTY with legal content as they had limited or no access to legal publications from or about the ICTY. ${ }^{36}$ One judge reported that he was unable to locate a copy of the Tadic judgment which he remarked was critically influential in a "legal and political sense." Two judges reported that they periodically received computer disks from the ICTY with bulletins about the Tribunal's recent work. Others cited informal "exchange of opinions" with colleagues as an additional source of information.

Participants offered suggestions to improve communication with the ICTY. One suggested that the ICTY regularly distribute its reports directly to judges and prosecutors. Another believed that more judges and prosecutors should visit the Tribunal. In addition, a judge encouraged visits by the highest officials from the ICTY to meet members of the local judiciary.

36. The ICTY website, <http://www.un.org/icty/index.html>, had not included documents in the local languages of $\mathrm{BiH}$ until after the survey was completed. 
V.

\section{Discussion}

The purpose of this study was to assess the perceptions and consequent attitudes of Bosnian judges and prosecutors involved in the adjudication of war crimes. The following discussion offers some interpretations of the major themes that emerged. In so doing, our goal is to offer a richer understanding of the impact of international criminal trials on a national judicial system. The survey results suggest that those international institutions that interact or are involved with the Bosnian legal system should take seriously the problems and resistances articulated by the study participants in formulating future directions. In addition, these perceptions may offer lessons about the ICTY's effect on Bosnian legal professionals that can be applied to the process of establishing an International Criminal Court. The findings suggest that it is essential to incorporate a context-specific understanding of an affected country and its judicial processes in order to enhance cooperation with and decrease resistance to institutions of international criminal justice.

\section{A. Context}

The legal professionals who participated in this survey were surprisingly open and candid in the interviews. However, it was apparent that certain topics provoked a significant emotional response, most clearly in the areas of war crimes and genocide. Across the board, participants avoided provocative questions that addressed the relationship of law to justice. For example, in response to questions regarding their role in refugee returns, the creation of a State supreme court for $\mathrm{BiH}$ or the prosecution of political leaders for war crimes, participants frequently resorted to the evasive statement that the question was "political" and therefore inappropriate. This response may reflect the traditional and narrowly defined role of the judge in a civil law system or participants' perspective on the role of law in a Communist society. It may also reflect their caution in making statements that may expose them to retaliation or retribution by the legislative and executive branches of government which wield tremendous power over the judiciary.

In addition, there was a strong association between the emotional response to particular topics and the participant's national origin. It was interesting that participants expressed few reservations regarding the confidential nature of the interview, despite the caution they displayed in answering certain questions. In fact, it became evident that a few had discussed their participation with colleagues. The researchers feel that, despite the difficult context in which these judges and prosecutors operate, their answers reflected an honest attempt to grapple with the issues raised.

\section{B. Professional Identity}

Given the ongoing criticism of the Bosnian legal system by members of international organizations such as UNMIB, JSAP and OHR, we were surprised 
to observe the extent to which the notion of "professionalism" dominated the views of the participants in this study. While the international community has considered Balkan politics primarily in terms of conflict between national groups, it has paid too little attention to other factors that may influence attitudes and behaviors, like professional identity. The judges and prosecutors in the sample reported that they maintained high ideals of integrity and respect for the rule of law. These precepts were accompanied by reverence for codified law that reflect the civil law tradition. In this system, there is no concept of judicial activism. While recognizing that injustice may be caused by political decisions, judges and prosecutors did not see themselves as empowered to use the law to ameliorate the negative consequences of these decisions. It is also possible that some legal professionals may have relied on the formal structure of the civil law tradition to mask their personal support for the goals of the politicians in power, particularly since they were communicating to an international audience.

Further, the participants reported anger and confusion over the criticisms by international lawyers who did not appear to understand the legal tradition of civil law countries or, if they did, were perceived as showing disrespect for the judicial system to which Bosnian legal professionals were devoted. These attitudes, coupled with the decision of the ICTY to combine common and civil law to the great confusion of our participants, may lead to a pervasive sense of being practitioners in a second-rate system. Judges and prosecutors therefore find themselves on the defensive, powerless in the face of an international community that rejects their beliefs. Prior to the war, judges and prosecutors were people of stature - community leaders with means and position. Having lost their homes, family members, and friends, these Bosnian professionals appeared to cling to their professional identities. Unfortunately, participants perceived international criticism of the Bosnian legal system as an attack on their professional identity. This perception by participants indicates that efforts by international organizations to enhance the professionalism of Bosnian judges and prosecutors should be designed with this vulnerability in mind. If Bosnian legal professionals experience educational interventions as denigrating their competence, such well-meaning programs run the risk of promoting resistance to, rather than cooperation with, international groups.

These findings do not tell the whole story. These legal professionals are beleaguered: not only are they criticized by those outside the country but they are under pressure from those within, particularly politicians and criminal elements who act with impunity. Since they are dependent on legislative and executive branch officials for fiscal and other resources, they are pressured to render decisions that are favorable to these authorities. Compounding this, threats to them or to their families, evidenced by abductions or beatings, place them in positions of great vulnerability with minimal protections. Given these pressures, it is significant that this sample of judges and prosecutors insisted on their integrity and consistently advocated independence of the judiciary. We must also emphasize that they recognize what needs to be rectified in their system if positive change is to occur - decent salaries paid regularly, protection from harm, 
competent judges, transparent decision-making and non-interference by politicians. Although they recognized that corruption (defined as bribery) was possible and perhaps even likely among some of their colleagues, they traced this to the poor pay and diminished quality of life. Further, they supported the law that prohibits judges from joining political parties.

There appears to be a disconnect between the views of Western legal experts and those of Bosnian legal professionals in this study. It centers on the question of influence or the appearance of influence on judicial and prosecutorial activities. Although it is not clear to what extent improprieties exist, the reports of such have been cited as justifications for large-scale reform of the Bosnian legal system. In order to promote an effective dialogue between these groups, Western experts need to acknowledge the expertise and strengths of Bosnian legal professionals. In addition, international representatives must articulate the justifications for the new professional standards that the international community seeks to inculcate within the national legal system.

Like the rest of the country's institutions, the legal system is coping with the transition from the pre-war Communist era. Our study suggests that the judges are open to change but the modifications required must occur within the larger context of transformation of the political system. Moreover, the influx of international lawyers and others who are perceived as promulgating a foreign system of law disempowers Bosnian professionals, heightens their ambivalence and potentially mitigates the positive effects that could result from the international presence.

There is no question that disparities in power color this process of evolution. Our findings suggest that the Western legal community may not be sufficiently sensitive to these issues in their concern to implement a "modern" system of law. Although international organizations have Bosnian nationals on staff, this level of integration is insufficient to overcome the perception among the Bosnian legal professionals we interviewed that the international community is imposing foreign values upon them. We suspect that the desired changes will require many years to implement fully. It is likely that a systematic and wellpaced process - one that more completely involves the Bosnian legal community in design of training, modifications of the law and which respects the integrity of the Bosnian legal tradition - will have a more profound and sustained impact on the legal system. Power disparities generate ambivalence, and attention to the resistances that reflect this ambivalence will further the goals of a truly independent and stable judicial system.

Finally, the rejection of the political process by members in our study of this professional class is disturbing. Since the members of our sample were highly educated and relatively well informed, their rejection of the political process has implications for the development of democracy in BiH. For many, "political" has come to be reflective of nationalism and war. If these judges and prosecutors see the need to withdraw from political participation, there is a danger that legal professionals will be further disempowered as they eschew the 
democratic process. If other educated individuals feel similarly, this will not augur well for an active citizenry fully engaged in democratic decision-making.

\section{Participants' Perceptions of the International Community and the ICTY}

We have described how our sample views the international community. These views influence their perspective on the ICTY as well. The international community responded to war crimes and genocide in Bosnia by establishing the first international war crimes tribunal since Tokyo. The difficulties in establishing the ICTY are well documented and include its inception in the midst of a war and a lack of financial and human resources as well as ambivalent support from world leaders. In the early years of the Tribunal its work suffered from lack of cooperation from authorities in Bosnia. Additionally, the narrow mandate of the international troops stationed as peacekeepers in Bosnia inhibited arrest of indicted war criminals. In the seven years since its creation, significant positive changes have taken place as financial support has increased, countries with peacekeeping troops on the ground have improved cooperation with ICTY prosecutors and the ICTY has clarified its practices and procedures. This study provides the opportunity to re-evaluate the practices and institutional arrangements of the ICTY in order to lessen resistance and encourage collaboration between these judicial entities.

The participants perceived the following areas of concern: location of the ICTY; judicial appointments; criticisms by international organizations of the Bosnian legal system; a misunderstanding of the hybrid nature of ICTY judicial procedures; the inherently political nature of a United Nations-sponsored ad hoc tribunal; and the lack of communication between Bosnian and Tribunal legal professionals. This constellation of factors has coalesced around a perception by Bosnian judges and prosecutors we interviewed that the ICTY, as well as those international legal organizations working in Bosnia, have contributed to the marginalization of Bosnian legal professionals. While most participants continued to support the concept of the ICTY, these concerns have placed them on the defensive and led to skepticism that undermines their support of the Tribunal.

Mass accountability for Bosnian war criminals necessarily requires the active participation of the Bosnian legal system because of the sheer numbers of suspects involved. Currently, because the ICTY assumes primary jurisdiction for war crimes, the Bosnian legal system largely has been bypassed or reduced to a subsidiary role in this process. The skeptical, even negative, attitudes of participants that we have described pose a significant risk to the long-term development of the Bosnian legal system and its integration into Western Europe. The findings indicate that current efforts of the ICTY and international institutions working to promote the Bosnian legal system have yet to overcome this negative perception. Five years after the signing of the Dayton Accords, the persistence of this skepticism is of grave concern. Greater attention needs to be paid not only to the political and financial limits on the Bosnian legal system but also to the more subtle psychosocial factors that sabotage professional identity and commitment to positive change. 
In 1993, when the ICTY was created in the midst of active conflict, important choices were made regarding the location and structure of the Tribunal. At that time, it was not possible to locate the Tribunal in the Balkans or to include participation by the Bosnian judiciary in trials. Participants' concerns about marginalization lead to the question of whether the original decision regarding the location of the ICTY and the exclusion of Bosnian legal professionals in its judicial ranks should be reconsidered. These tactical decisions, taken at the Tribunal's inception, are examples of choices made in the context of armed conflict that now might be revisited.

In the findings, we have described a series of factors that have contributed to resistance to the ICTY. The synergistic effect of these factors requires closer examination. The Bosnian legal system has been under intense international scrutiny particularly since the end of the war. Bosnian legal professionals have received contradictory signals from the ICTY and international organizations. For example, under the Rome Agreement, Bosnian authorities lawfully can arrest and prosecute alleged war criminals only subject to ICTY approval. At the same time, international organizations like UNMIB, JSAP and OHR continue to criticize the Bosnian judicial system for its lack of independence, incompetence and corruption. These evaluations send the message to Bosnian judges and prosecutors that fair war crimes trials are impossible in their own country. On the one hand, international organizations have reported that local justice is vulnerable to influence; some judges may be corrupt, incompetent, and/or influenced by nationalist politics. On the other hand, this is not universal. The net effect of these mixed messages may be to amplify the negative overtones of these signals. Thus, the overwhelming impression that Bosnian legal professionals have of the ICTY and international organizations in Bosnia is that these institutions, with few exceptions, have little respect for the Bosnian legal system. In pursuing their own predetermined agendas, without meaningful input from Bosnian legal professionals, international organizations run the risk of undermining the very goals they are trying to achieve.

Moreover, many Bosnian legal professionals perceive the ICTY and its procedures as indicating that the Bosnian legal system is substandard. Bosnian judges and prosecutors perceive the choice of a hybrid set of procedures that embody primarily common law as a negative evaluation of the civil law system and a challenge to the precepts of Bosnian legal professionals. Each of these legal systems has a distinct culture. The structure of a civil law system results in a more rapid trial, fewer witnesses and the role of the judge is more narrowly defined. ${ }^{37}$ For many Bosnian legal professionals, the common law system is inaccessible and, by extension, the ICTY.

Bosnia is a virtual protectorate of the international community. Across national groups, participants perceived that they occupied a diminutive status in this arrangement. It became clear among our sample that they did not consider themselves to be co-equal partners in the design and implementation of many of

37. See Miruan R. Damaška, The Faces of Justice and State Authority 19, 51 -3 (1986). 
the programs intended to rebuild their legal system and their country. The attitudes toward the international community were multifaceted and strongly colored participants' views of the ICTY: some were grateful to the world community for ending the war; others were angered by the time that it took for intervention to occur; and still others resented the support for a multicultural, unified Bosnia. Against the backdrop of the helplessness engendered by severe personal loss, the lack of information about the ICTY may compound the implicit message that the Bosnian judiciary and its prosecutors are at best, barely acceptable, and at worst, irrelevant. Bosnian legal professionals have lost status and their social contribution has been denigrated as a result of the war. Compounding the powerlessness that results from these losses, they now find themselves sidelined in the process of reconstruction. In response, nationalist perspectives are supported, myths about the ICTY's bias are perpetuated and its positive contributions are minimized.

The findings suggest that national identity influences the participants' opinions regarding the ICTY. For example, those Bosnian Croat and Bosnian Serb participants characterizing the ICTY as a "political" body simultaneously delegitimize the Tribunal and bolster their own integrity as legal professionals. Thus, to label the ICTY as "political" enables these participants to dismiss its judgments as the result of a legal charade and to reaffirm their own fealty to the principles of neutral adjudication and professionalism. Moreover, this labeling also may serve to mask the political biases of the participants and avoid acknowledgment of the consequences of their political choices. Further, it is essential that we recognize the ICTY as a political body in its inception, judicial selection and in the rules and procedures it promulgates. ${ }^{38}$ Moreover, its activities and decisions have far-reaching effects within each national group and within the state as a whole. The absence of a frank discussion between the ICTY and Bosnian legal professionals regarding the perceived political dimensions of the ICTY may have served indirectly to enhance resistance to the Tribunal within Bosnia.

It is abundantly clear that Bosnian legal professionals did not have accurate information about the ICTY. At best, this confusion has generated misunderstanding on the part of those legal professionals who supported the ICTY. At worst, the absence of correct information has fueled suspicion and hostility among those Bosnian Croat and Bosnian Serb participants who viewed the ICTY as the authoritative and critical voice of the international community. For these, the ICTY contradicted their own understanding of the role their national group played in the war relative to that of other groups. However, all participants, even those who displayed outward hostility toward the ICTY, expressed genuine interest in receiving more and direct communication from the Tribunal.

38. Former President of the ICTY, Gabrielle Kirk McDonald, has acknowledged the political nature of the Tribunal: "First of all, we are a political court. We were established by the Security Council and that makes us political because the Security Council is a political body. And as President, I have acknowledged that. That does not mean that we act in a political way. The judges are independent." Interview with Gabrielle Kirk McDonald, supra note 11. 
The few participants who have had personal exposure to the ICTY came away with a deep respect for the Tribunal and the professional integrity of its staff, regardless of their national identity. Their experiences provide reason to believe that negative attitudes of some Bosnian legal professionals may be changed by increased exposure to the Tribunal.

\section{Accountability, Responsibility and Genocide}

Participants hold strong views regarding who is responsible and who should be held accountable for atrocities committed during the conflict. ${ }^{39}$ The cohesion of views among participants of the same national group again indicates that war experiences of participants, their self-identification with a particular national group and their exposure to dominant narratives about the role of their national group in the conflict exert a profound impact. The willingness of participants to demand accountability for particular individuals varied substantially with national group - Sarajevo Group participants being most specific. It is noteworthy that participants - Bosniaks and Bosnian Croats - who refer to atrocities that have been corroborated by international human rights groups and United Nations-sponsored bodies appear more likely to demand international accountability for the perpetrators of these crimes. Other participants - predominately Bosnian Serb - claim victimhood and yet describe no specific atrocities or war crimes. For them, accountability seems to be an abstract concept.

All participants seek to present the war experience of their national group as that of victims. However, the international community sees Bosnian Serb and Bosnian Croats as aggressors. This disparity in viewpoints may explain the responses that were defensive or evasive. The insistence of these legal professionals on recognition of the suffering or misunderstanding of their national group may have been used to deflect unspoken or presumed criticism by the researchers. While the experience of each national group provides a unique perspective on the conflict, the lack of a public discussion within each national group critical of the war atrocities carried out in the name of that national group solidifies and privileges one "truth" at the expense of all others. Although the findings indicate this pattern is observed in response to questions about accountability and responsibility in general, nowhere is it more pronounced than in the responses to the topic of genocide.

When asked their legal opinion about the occurrence of genocide during the war, participants responded by recounting the politically accepted version of events from the perspective of their national group. Bosniak participants were unequivocal and consistent in their statements that genocide against Bosniaks occurred during the war, while Bosnian Serb participants tended to state that genocide occurred against all three sides, that they had no knowledge of any acts of genocide or that genocide did not occur at all. Bosnian Croat legal profes-

39. In the local language participants spoke during the interviews, the word for "responsibility" is the same as "accountability." Nevertheless, it was possible to distinguish these two concepts based on the context in which the word was used. 
sionals were willing to state that genocide occurred, but if so, that all three sides had suffered it. The statement that genocide occurred on all three sides serves indirectly to acknowledge that the armed forces of the participant's national group had committed mass war crimes while allowing the speaker to claim the status of victim for his or her national group. The diffusion of responsibility that characterized this opinion is ominous.

There are two immediate consequences to turning each national group into co-equal victims of genocide. First, it ignores the historical record that indicates that some suffered more than others. For example, this opinion implicitly trivializes events like the Srebrenica massacre. In addition, the ideal of co-equal accountability obfuscates the facts and recapitulates the pernicious historical revisionism following World War II that has haunted the former Yugoslavia. Second, this idea has radical implications for international war crimes prosecutions. If all sides to the conflict are equally guilty, then the ICTY should indict and try equal numbers of Bosniak, Bosnian Serb and Bosnian Croat war crime suspects - an expectation articulated by many Bosnian Croat and Bosnian Serb legal professionals. This perspective also acknowledges that the judges and prosecutors themselves understand the significant political ramifications of the trials. The disdain for the "political nature" of the ICTY reflects the reality that the Tribunal's prosecutorial choices validate one version of events over others. The principle of proportional prosecution, suggested by some of the participants, would lead to under-prosecution of Bosnian Serb perpetrators of war crimes and/or over-prosecution of Bosniaks and Bosnian Croats since there is a disparity in atrocities committed by members of particular national groups. Therefore, equal numbers of prosecutions do not produce equal justice.

The divergence among the groups is particularly striking considering that we asked participants to state their legal opinion as to whether genocide occurred. Yet, with few exceptions, participants did not refer to a legal definition of genocide. Rather their responses suggested that participants used the term "genocide" to refer generally to war atrocities. As noted, we view this generalization of the use of the term genocide as a mechanism to diffuse responsibility for the war. Their interpretation demonstrated how identity and national consciousness can color legal reasoning. The lack of legal precision in their responses may have indicated that it was difficult for participants to remain objective when they discussed this controversial issue.

The difficulty that participants had in discussing responsibility and accountability for the war raises serious implications for the ability of Bosnian legal professionals to conduct impartial trials of accused war criminals. Participants prided themselves on their objectivity and their ability to adjudicate matters before them impartially. To the extent that they expressed reservations about conducting national war crimes trials, they stated that political pressures may corrode due process protections. However, the strong association between the "legal" opinion offered on genocide and the national group identity of participants indicates that Bosnian legal professionals may not be neutral on issues regarding accountability for war crimes and genocide. These attitudes are cause 
for concern. At the time of this study, there existed a gross disparity in the numbers of war crimes trials held in the Federation and the RS (where virtually none had taken place). While we recognize that war crimes trials require the active participation of police and government structures, we share the concern expressed by many participants that the Bosnian judicial system may not be prepared fairly to adjudicate the trials of those accused of war crimes.

\section{E. Social Reconstruction and Reconciliation}

The concept of reconciliation in post-war societies remains elusive. Further, the positive contribution of international criminal trials to this process, while widely and uncritically accepted, remains an empirical question. ${ }^{40}$ Materials produced by the ICTY and comments by its supporters reiterate the importance of war crimes trials to the process of national reconciliation. ${ }^{41}$ Generally, reconciliation refers to a process by which peoples who were formerly enemies put aside their memories of past wrongs, forego vengeance and give up their prior group aspirations in favor of a commitment to a communitarian ideal. Since "reconciliation" has theological overtones that reflect the Christian religious tradition, we have chosen to use the term "social reconstruction" to describe the evolution of social institutions, economic development, community-building and person-to-person connection that may underlie the commitment of people to live together.

Reconstruction is a contested notion. Our study suggests that the widely held belief that war crimes trials - which individualize accountability - contribute to social reconstruction may reflect more of an aspiration than a reality. In fact, our findings indicate that many Bosnian Croat and Bosnian Serb legal professionals do not view criminal trials as integral to social reconstruction. An analysis of the responses of our participants suggests that social reconstruction may not occur when people are faced with judicial decisions that do not correspond to their perceptions of what happened, i.e., their "truth." Evidence that is sufficient to produce a verdict in a court of law may not be sufficient to override solidified national group perspectives among the ranks of some legal professionals. These narratives that reflect national or "ethnic" history, whether contemporary or ancient, profoundly influence how our sample viewed individual verdicts. The participants in this study operate within a political context in which national identities are inscribed. It is possible that transformation toward a more open and democratic society will enable these judges and prosecutors to separate themselves from national group allegiances and to articulate thinking that is different from the current national stories about the war. Thus, our study highlights how war experiences and national group narratives may work in tandem to isolate and increase political distance among national groups.

40. See Michael IgnatiefF, The Warrior's Honor: Modern Conscience 164-90 (1997). Ignatieff describes the "articles of faith" that underlie the commitment of the world community to international trials for war crimes. He asks: "What does it mean for a nation to come to terms with its past?"

41. Morris \& Scharf supra note 3; Outreach Program Proposal supra note 5; Kritz, supra note 12 at 128-29. See also supra note 11 . 
For example, responses to the question of the relationship between war crimes trials and social reconstruction once again reflected national group perspectives. For Bosniak judges and prosecutors, the widely held belief that social reconstruction follows from individualizing guilt was a valid construct. However, Bosnian Serb legal professionals saw no relationship between trials and social reconstruction. In fact, they focused primarily on living amiably next door to their Bosniak and Bosnian Croat brethren but not in one geographical space. They seemed more interested in promoting the regional governmental structures that were established at Dayton within the RS rather than in strengthening the State institutions. Thus, the ICTY was perceived as irrelevant while issues of economic reconstruction and job creation were critical.

Our sample of Bosnian Croats participants showed more variation in their responses. Most were positive about the feasibility of a unified state but qualified their remarks by indicating that such a process would take many years. Two advocated a three-entity solution, living side-by-side. Most felt that the ICTY over time would contribute to the political stability of the country. While some focused on acknowledgement of their victimhood and retribution as the next step, others emphasized the importance of economic development. As the recent ESI and ICG reports suggest, the existence of the shadow state of HercegBosna under the aegis of the Croatian Democratic Union (hereinafter Hrvatska Demokratska Zajednica or HDZ) has led to a de facto separation that OHR seeks to eradicate. How the judges and prosecutors see their roles in this shadow state was not apparent, although they articulated support for the full integration of the judicial systems, especially in Mostar. It is too soon to evaluate the impact of the death of Croatian president Tuđman and the defeat of the HDZ party in the recent elections, although the apparent rigidity of the HZD in Herzegovina suggests that significant changes will not occur in the immediate future.

Only a minority of Bosnian legal professionals in our sample believed that war crimes trials were a vehicle for social reconstruction. Diplomats, world leaders, ICTY officials and human rights proponents may be advocating that the ICTY achieve an objective - reconciliation - for which there is no broad-based acceptance among our participants. The data suggest that Bosnian legal professionals do not necessarily aspire to a future that is a reconstruction of pre-war social arrangements. Therefore, the contribution of the ICTY to social reconstruction is in question since it may resonate only with the beliefs of a minority of the legal profession.

Many legal commentators have urged the ICTY to use its judgments to promulgate an authoritative historical record of the conflict in the former Yugoslavia that will serve as the basis for social reconstruction. ${ }^{42}$ In recent years,

42. Payam Akhaven, Justice in the Hague, Peace in the Former Yugoslavia? A Commentary on the United Nations War Crimes Tribunal, 20.4 Hum. RTs. Q. 737, 782-85 (1998); Aryeh Neier, Rethinking Truth, Justice, and Guilt after Bosnia and Rwanda, in Human Rights in Polttical Transitions: GetTysburg to Bosnia 39, 49 (Carla Hesse \& Robert Post eds.,1999) [hereinafter Human Rights in Political Transitions]; Ruti Teitel, Bringing the Messiah Through the Law, id. at 177-90; Naomi Roht-Arriaza, The Need for Moral Reconstruction in the Wake of Past Human Rights Viclations: An Interview with Jose Zalaqett, id., at 195-209. See also supra notes 10, 11 ; 
there has been considerable debate over the necessity of a public accounting for past human rights abuses to promote the rule of law and a strong and democratic society. ${ }^{43}$ Traditionally, this debate has been framed as choice between extremes: utter impunity v. individual trials. The dilemma is how to respond to past gross abuses in a manner that allows multiple communities with varied needs and goals to learn to live together again. Ultimately, while justice and accountability may be significant contributors to the process of social reconstruction, our findings indicate that war crimes trials should be conceptualized as but one aspect of a larger series of possible interventions.

This study underscores the need to attend to the competing claims of national groups, whether they are victims or aggressors. It is critical to reexamine the assumption that remembrance - in the form of legal record - is the foundation for social reconstruction. For some groups, forgetting may be the only avenue to community building. For others, acknowledgement of past suffering may be the cornerstone of social repair. However, our findings indicate that differing responses to the war create competing needs for avenues for recovery. In the aftermath of mass violence, there may not be a consensus about who were victims and who were perpetrators. Although international trials render verdicts based on an examination of "facts," the responses of our participants indicate that their perception of truth may outweigh the facts as determined by an international body. Consequently, for Bosnian Serb and some Bosnian Croat legal professionals, international trials were construed as privileging the needs of some voices over others.

Across national groups, participants in this study believed that all who were responsible for war crimes must be held accountable. Nevertheless, the findings suggest that the ingredients and priorities for social reconstruction are influenced by whether an individual is a member of a national group that is perceived by the international community as a victim or a perpetrator. In addition, we suggest that those who are members of victimized national groups have a different timeframe for initiation of war crimes trials from those whose political leaders initiated the war but who themselves did not directly commit atrocities. For the former, individual criminal trials are an immediate and overriding goal; for the latter, social reconstruction is a long-term process that may not involve criminal trials. We must honor the needs of victims of gross human rights abuses. However, our findings suggest that if social reconstruction is a worthwhile objective, it is important to achieve it in a framework that engages those who, while not directly acting as perpetrators, supported the aims of those who promulgated crimes of war and genocide. For the international community the question is what are the limits of amnesia.

Martha Minnow, Between Vengeance and Forgiveness: Facing History After Mass GenoCIDE (1998).

43. Diane F. Orentlicher, Settling Accounts: The Duty to Prosecute Human Rights Violations of a Prior Regime, 100 Y ALE L.J. 2537. See Carla Hesse \& Robert Post, Introduction, to Human Rights in Polmical Transitions, supra note 42, at 13-31; Ken Roth, Human Rights in the Haitian Transition to Democracy, id. at 93-127. 
VI.

\section{RECOMMENDATIONS}

These findings indicate needed improvements in the areas of judicial and prosecutorial independence, continuing education, and improved communication and collaboration among legal professionals across national groups. In addition, the findings suggest that there are several areas in which changes could be made to enhance the acceptability of international criminal trials to Bosnian legal professionals. To these ends, we make the following recommendations:

1. We support legislation that ensures the independence of the judiciary in both entities in $\mathrm{BiH}$. In particular, we encourage action to establish appropriate salaries - timely paid - and adequate security measures.

2. We support the institutionalization of regular and sustained professional contact between legal professionals in each entity. In particular:

a. continuing education programs for Bosnian legal professionals should be expanded and should include discussions of war crimes trials, international humanitarian law and international human rights standards;

b. continuing education programs should be conducted by international professionals who have a sound knowledge of the Bosnian legal system and tradition; and

c. continuing education programs should be conducted as soon as possible by Bosnian legal professionals and/or professionals with a thorough grounding in the civil law tradition.

3. We support the strengthening of the independent legal associations recently established. These associations should continue to promote review, development and dissemination of ethical and professional standards for lawyers and judges.

4. We strongly encourage the Tribunal to pursue the option of conducting trials on the territory of $\mathrm{BiH}^{44}$ We suggest that such trials be held in the region in which the alleged incidents occurred.

5. We suggest that war crimes trials in each entity be conducted by a panel of three judges, one of whom one should be a judge who is not a citizen of $\mathrm{BiH}$ or of any of the states of the former Yugoslavia. Appellate review of such trials should also be conducted by a three-judge panel, one of whom should be a judge who is not a citizen of $\mathrm{BiH}$ or of any of the states of the former Yugoslavia. Such measures are warranted because the majority of war crimes trials will be held in the domestic courts of $\mathrm{BiH}$ and the vulnerabil-

44. In establishing the ICTY, the Security Council, pursuant to Resolution 827 , stated that "The Tribunal may sit elsewhere [outside of the Netherlands] when it considers it necessary for the efficient exercise of its functions," supra note 4. 
ity of Bosnian judges and prosecutors to improper political influences will continue for the foreseeable future.

6. We strongly support a rigorous protection program for witnesses, judges and legal professionals involved in war crimes trials held on the territory of $\mathrm{BiH}$. Adequate protection necessarily must be offered during the investigation, trial and appellate proceedings. The offer of meaningful resettlement must be offered in appropriate instances. Such a program may require the financial support and active participation of the international community.

7. We support the concept of an ICTY outreach program. This program should pay particular attention to communication with Bosnian legal professionals in the local language. In particular, the program should:

a. establish an advisory council of Bosnian legal professionals to determine the information needs of the legal community and to cooperate with the ICTY to address those needs;

b. focus on the on-going and rapid dissemination of accurate information regarding ICTY activities. This information should be disseminated in the local language through print, computer and videotape;

c. offer seminars and, preferably, other forms of face-to-face interaction with legal professionals and officials of the ICTY to address areas of misunderstanding, ignorance and concern. These fora may be live or conducted through the medium of telecommunications;

d. rotate Bosnian legal professionals through the ICTY in The Hague to provide first-hand observation of facilities, procedures and judicial processes. The criteria for selection should be transparent;

e. emphasize content that addresses such issues as the priorities of indictments for the court, explanation of the hybrid nature of the procedures, limitation of the court's purview and the intended impact of the court's decisions in Bosnia.

8. We recommend that communication between the ICTY and the people of $\mathrm{BiH}$ be enhanced. Communications should be in the local language and all branches of the media should be utilized. Civil society should be encouraged to include representatives of the ICTY at community-sponsored events including professional conferences and nongovernmental organizations' meetings and events. Although press conferences are useful, officials from The Hague visibly should be present at such activities.

9. We suggest that opinion leaders and service providers such as educators, health professionals, journalists, leaders of Bosnian nongovernmental organizations, representatives of civil society, social 
service providers and writers also should be rotated through the ICTY or brought together from both entities to meet in The Hague to address areas of misunderstanding, ignorance and concern. The criteria for selection should be transparent.

10. We urge the ICTY to convene and visibly be present at periodic community meetings in $\mathrm{BiH}$. These meetings should be held in various locations throughout the country and include towns and villages outside of the larger cities.

11. We strongly encourage OHR to undertake the organization of an inter-entity council to examine a range of alternative mechanisms to promote social reconstruction. Since Bosnian legal professionals do not uniformly connect war crimes trials to social reconstruction, such a council should analyze and make recommendations to promote democratization, open communication and a free press, cross-entity small business development, and religious and cultural tolerance. Members of this council should reflect a balance with respect to gender and national origin and include representatives from academia, primary and secondary education, the media, nongovernmental organizations, professional associations, and the religious communities.

12. We suggest that the findings of this study may offer insights that enhance the effectiveness of the International Criminal Court. In the institutional structures and arrangements - yet to be created procedures, positions and resources should be established and devoted to maximize the impact and understanding of the trials within the directly affected communities. In particular, procedures and programs should address the following issues:

a. the trials should be located on or as near as possible to the territory in which the alleged incidents occurred;

b. the goals, objectives, judicial selection, priorities for indictment and other mechanisms of the ICC should be transparent and communicated effectively in the local language of the country in which the alleged incidents occurred;

c. the rules of evidence and procedure governing the ICC should take into account the major legal traditions. To the extent that there is flexibility in the rules, their application should be responsive to the legal culture of the country in which the alleged incidents occurred;

d. the procedures governing the investigation, trial and appellate phases should be communicated effectively in the local language to members of the legal profession in the country in which the alleged incidents occurred; 
e. innovative ways of including representatives of the affected country's judiciary in the adjudicative process should be explored; and

f. additional interventions that are different from, but complementary to trials, such as facilitating culturally accepted mechanisms of justice, should be considered. 


\section{ApPEndix A}

Justice, Accountability, and Reconstruction in the Former

Yugoslavia:

An Interview Study of Bosnian Judges and

Other Key Informants ${ }^{45}$

Question coding:

Questions in plain text: demographic information.

Questions in italics: How does the work of an international war crimes tribunal contribute to local efforts at social reconstruction?

Questions in bold type: How do war and changes in identity influence the administration of justice?

QUESTIONS IN SMALL CAPS: WHAT IS THE ROLE OF JUSTICE AND THE LEGAL SYSTEM IN SOCIAL RECONSTRUCTION?

Interview Code \#

Disclosure Read

Subject Agreed

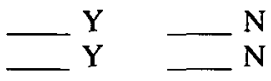

I.

DEMOGRAPHICS

A. Experience

How did you become a judge?

Where were you educated?

Have you ever been educated outside Yugoslavia?

How long have you been a judge?

Why did you become a judge? (motivation)

What do your professional contacts with judges in the other entity consist of?

\section{B. Personal background}

When were you born?

Where have you lived and during what time periods?

II.

Role OF THE JUDGE

What do you see as the judge's most important role?

-Inside the courtroom?

-Outside the courtroom?

How has the 1992-1995 war affected your motivations for being a judge?

How has it affected your career path?

Are the national identities of the parties in your courtroom proportionately different than they were before the war?

45. This questionnaire was translated into the three local languages of $\mathrm{BiH}$. 
Is the national identity of parties included in courtroom records?

Has that changed since the war?

Do you believe that judicial decisions can play a role in changing people's attitudes? Can you give us any examples where this has happened?

In your opinion, how has law and its application changed since the war?

What is the role of the judge with respect to the return of refugees? (Should judges apply a strictly legal analysis to the return of refugees to their homes, or should they allow for the fact that there is a housing shortage and the return of refugees could produce a domino effect?)

III.

IDENTITY OF AND IMPACT OF THE WAR UPON THE JUDGE

\section{A. National background}

With which national groups do you identify and why?

With which groups do (did) your parents identify?

Before the war, did you identify with a different national group?

\section{B. Impact of the war}

What has been the most significant change in your life since the war broke out? Has your health been affected by the war?

Did any of your family or friends die or disappear or become injured during the war?

Were you ever in any army? If so, when?

Did you serve as a military judge in the 1992-1995 war?

Have you ever been a member of a political party?

Are you politically active now?

IV.

DOMESTIC EFFECTS OF THE ICTY

A. Legal definitions

HOW DO YOU DEFINE RULE OF LAW?

WHO IN BOSNIA-HERZEGOVINA TODAY BELIEVES THAT THE RULE OF LAW IS THE best way to resolve disputes? Judges? Attorneys? The public? PolitiCAL LEADERS?

HAS THIS CHANGED SINCE THE WAR?

Do YOU VIEW THE JUDICIAL SYSTEM IN BoSNIA-HERZEGOVINA AS AN EFFECTIVE WAY TO RESOLVE CONFLICTS?

IF YES, IS THIS TRUE FOR DISPUTES BETWEEN PERSONS OF DIFFERENT NATIONAL GROUPS?

IF NO, WHY NOT, AND IS IT DIFFERENT FOR DISPUTES BETWEEN PERSONS OF DIFFERENT NATIONAL GROUPS?

DO YOU THINK THAT YOUR COLLEAGUES (IN YOUR CANTON/REGION) CAN PROVIDE A FAIR TRIAL UNDER THE CURRENT, DIFFICULT CONDITIONS? 
How would you explain legal accountability?

How does accountability influence your decisions in court?

Should individuals be held more or less accountable for their actions during periods of warfare?

- If so, how? If not, why not?

What do you think the relationship is between ensuring the widespread accountability of war criminals and social progress and economic development in Bosnia-Herzegovina?

\section{B. Dayton Accords and formal structures}

What role do the Entity constitutions of the RS and the Federation PLAY IN RECONCILIATION AND SOCIAL RECONSTRUCTION?

DOES INTERNATIONAL LAW IMPACT YOUR COURTROOM? IF SO, HOW?

WHAT DO YOU CONSIDER THE HIGHEST LAW OF THE LAND?

Should a Supreme Court of Bosnia-Herzegovina be Created?

\section{Concepts of accountability}

In your legal opinion, did genocide happen anywhere in Bosnia-Herzegovina? Against whom did these acts of genocide occur?

Do you hold anyone accountable for the war?

Do you think that bringing war criminals to trial can deter future war crimes?

\section{Knowledge of the ICTY}

What do you think about the ICTY?

What would you like to see the ICTY accomplish?

What changes would you make to the current processes or structure of the ICTY?

Who should the ICTY focus upon? The persons of the highest rank, like Milošević, or anybody who participated in war crimes?

What do you think others (your neighbors, friends, colleagues) would like to see them do?

Where should war crimes trials be held?

What do you think of the practice of sealed indictments?

How does the ICTY affect life in Bosnia-Herzegovina?

Do you think that citizens of Bosnia-Herzegovina are interested in the activities of the ICTY? Should they be?

Does the ICTY affect the process of "making up"?

Does it affect the process of reconstruction and redevelopment?

Do you think the ICTY affects people's perceptions of accountability regarding the war in Bosnia-Herzegovina?

What cases have you been following at the ICTY?

How do you get your news regarding the ICTY?

How has the ICTY affected proceedings in your courtroom?

Have you sent a case to the ICTY? 
Been asked for evidence from the ICTY?

How do the Rules of the Road impact your courtroom?

Do other actions of the ICTY, such as decisions, indictments, and appeals, play a role in your own decision-making process?

V.

Domestic War Crimes Trials

What is a WAR CRIMES TRIAL WHEN CONDUCTED Within BosNia-HeRzegoVINA? HOW DO YOU IDENTIFY SUCH A TRIAL?

Do DOMESTIC WAR CRIMES TRIALS HAVE AN EFFECT ON SOCIAL RECONSTRUCTION?

CAN You give us EXAMPLES OF ANY OF THESE?

[Provide closure for people and their communities; stimulate recovery and reconciliation, reconstruction; deter future war crimes]

HAVE YOU HAD A WAR CRIME TRIAL IN YOUR COURTROOM?

IN YOUR COMMUNITY?

Please tell us about that trial. (What was the Result of the TRIAL? WHAT WERE THE EFFECTS ON YOUR COURTROOM? WITHIN YOUR COMMUNITY?)

HOW WAS THAT TRIAL DIFFERENT FROM OTHER TRIALS IN YOUR COURTROOM?

[IF THE DECISION WAS NOT MADE BY THIS JUDGE. . .] WAS IT A TYPICAL RESUlT? IN YOUR OPINION, WAS THIS RESULT THE BEST ONE POSSIBLE?

IF NOT, WHAT ARE THE SPECIFIC CONDITIONS THAT WOULD HAVE MADE IT A FAIR TRIAL?

WHAT DID/DO YOU/WOULD YOU DO TO ENSURE A WAR CRIMES TRIAL WOULD BE FAIR?

Is LIFE TOGETHER IN BOSNIA-HERZEGOVINA POSSIBLE?

IN CLOSING:

Do you have any questions that you would like to ask us?

Are there any questions that we should have asked you that we have not?

Thank you / Hvala! 
APPENDIX B

TABLE 1

Demographics of Sample-Judges

\begin{tabular}{llc}
\hline \multicolumn{2}{l}{ PERSONAl AND PRofessional } & Background OF Judges \\
\hline Number of Judges & Number & Percentage \\
Median Age & 26 & $100 \%$ \\
Median Years as Judge & 48.5 & - \\
Female & 13.5 & - \\
Male & 4 & $15 \%$ \\
Bosnian Serb & 22 & $85 \%$ \\
Bosnian Croat & 8 & $31 \%$ \\
Bosniak & 10 & $38 \%$ \\
WARTIME ExPERIENCE & 8 & $31 \%$ \\
Lost Housing & & \\
Relative Injured or Killed & 11 & $42 \%$ \\
\hline
\end{tabular}

TABLE 2

Demographics of Sample-Prosecutors

\begin{tabular}{llc}
\hline Personal ANd Professional BaCKGround of Prosecutors & & \\
\hline & Number & Percentage \\
\hline Number of Prosecutors & 6 & $100 \%$ \\
Median Age & 49.5 & - \\
Median Years as Prosecutor & 17 & - \\
Female & 2 & $33 \%$ \\
Male & 4 & $67 \%$ \\
Bosnian Serb & 1 & $17 \%$ \\
Bosnian Croat & 2 & $33 \%$ \\
Bosniak & 3 & $50 \%$ \\
\hline WARTiMe ExPERIENCE & & \\
\hline Lost Housing & 2 & $33 \%$ \\
Relative Injured or Killed & 2 & $33 \%$ \\
\hline
\end{tabular}


APPENDIX C

What is the Supreme Law of the Land? ${ }^{46}$

\begin{tabular}{lll}
\hline BOSNIAK & CROAT & SERB \\
\hline BiH Constitution & Federation of BiH Constitution & RS Constitution \\
The Constitution & The Constitution & RS Constitution \\
BiH Constitution & Federation of BiH Constitution & RS Constitution \\
BiH Constitution & Federation of BiH Constitution & RS Constitution \\
BiH Constitution & BiH Constitution & RS and BiH \\
BiH Constitution & BiH Constitution & BiH Constitution \\
BiH Constitution & BiH Constitution & RS Constitution \\
BiH Constitution & BiH Constitution & RS or BiH Constitution \\
BiH Constitution & The Constitution & RS Constitution \\
BiH Constitution & Federation of BiH Constitution & \\
BiH Constitution & BiH Constitution & \\
\hline
\end{tabular}

46. Thirty-one out of 32 participants responded to this question. 
APPENDIX D

Should the Supreme Court of Bosnia-Herzegovina be created? ${ }^{47}$

\begin{tabular}{lll}
\hline BOSNIAK & CROAT & SERB \\
\hline YES & "Political question" & NO \\
YES & YES & NO \\
YES & "under certain conditions" & NO \\
YES & YES & NO \\
YES & YES & NO \\
YES & YES & YES \\
YES & YES & NO \\
YES & YES & YES \\
YES & NO & NO \\
YES & NO & \\
& YES & \\
\hline
\end{tabular}




\section{APPENDIX E}

1. In your legal opinion, did genocide happen anywhere in BosniaHerzegovina? ${ }^{48}$

2. To whom/Against whom?

\begin{tabular}{lll}
\hline BOSNIAK & CROAT & SERB \\
\hline YES & YES & YES \\
"In this country there was & "Against all three nations." & "To all three peoples." \\
too much genocide." & & \\
"Aggression on BiH as & & \\
recognized by Security & & \\
Council resolution." & &
\end{tabular}

YES

"Against Muslim and Croat peoples, the nonSerb peoples."

YES

“. . . personally I don't' have any information so I can't tell you where that happened and what happened."

YES

"It was not "ethnic cleansing.' It did happen on all sides, but you cannot compare the examples. There is Srebrenica."

YES

"I think that genocide occurred against Bosniak people."

\section{DO NOT KNOW}

“. . .I am talking about

legal assessments of certain acts, and I can't give only approximate judgments."

YES

". . .against all three people, against all three nations."

\section{PROBABLY}

"I think it was done by all to everybody"
YES

"What I have heard is that there was genocide everywhere."
YES

"Against everybody. It all depends on who happens to be in what kind of situation at the time. . It's only the question of possibility."

YES

“. . Serb aggression was surely genocide against the Bosniak and Croat people." "I am positive that it was first created against Bosniak and Croat people, I really don't know if genocide occurred on Serb[s]."
NO

"In the area of my supervision I think not."

48. Thirty-one out of 32 participants responded to this question. 


\begin{tabular}{lll}
\hline BOSNIAK & CROAT & SERB \\
\hline YES & YES & YES \\
"It is a well known fact." & "Genocide took place on & "Against all ethnic \\
"We all know, and starting & all sides." & groups." \\
with Srebrenica we all & &
\end{tabular}

with Srebrenica we all

know against whom."

"Well, there was some

genocide against Croats."

YES

"Here, the most against

“That's a political

question."

I DO NOT KNOW

Muslim people." "Mostly, mostly against Muslims."

YES

". . a horrible one."

"School example of genocide in Srebrenica."

"Against Bosniaks."

"Against others, only

murders, but not

genocide."

\section{YES}

"If you start from the definition of genocide used by the. . .Tribunal, I think that in relation to

Bosniaks, the genocide did happen, especially in certain parts."

YES

"I don't even want to talk about Bosnia-Herzegovina. In this town, in ten days over 3,000 people were killed. If that's not genocide, I don't know what is." "Here, against Bosniaks."

YES

"[A]gainst Bosniaks in Visegrad ... Mass slaughters, mass killings. Expulsions, rapes. And all done along strictly ethnic lines, without any reason, any logical reason ... [A]gainst everybody else was much, much smaller in scale."
YES

"Against all three peoples. All of them committed genocide, some more, some less, but all three sides committed genocide."

YES

". . .everywhere, all three sides." “. . .certain sides had more power. . ." "And as usual, people who are least ready suffer the most."

\section{MAYBE}

"I don't think there was a real genocide anywhere in $\mathrm{BiH}$, the full one. In some ways, there was a genocide, in others not actually, you didn't have one people actually completely wiped out."

\section{YES}

". . .on Bosniak people that happened." "You just have as example Srebrenica. And other places similar to Srebrenica."
"I do not want to speak about it."

NO

"I don't have any evidence and information whether it happened somewhere. In our area, I have no information." 